\title{
Lithium, Oxygen and Magnesium Isotope Systematics of Volcanic Rocks in the Okinawa Trough: Implications for Plate Subduction Studies
}

\author{
Zhigang Zeng ${ }^{1,2,3, *} \mathbb{C}$, Xiaohui $\mathrm{Li}^{1}{ }^{1}$, Yuxiang Zhang ${ }^{1,4}$ and Haiyan $\mathrm{Qi}^{1,4}$ \\ 1 Seafloor Hydrothermal Activity Laboratory, CAS Key Laboratory of Marine Geology and Environment, \\ Institute of Oceanology, Chinese Academy of Sciences, Qingdao 266071, China; \\ xiaohuili0526@foxmail.com (X.L.); yxzhang@qdio.ac.cn (Y.Z.); qihaiyan@qdio.ac.cn (H.Q.) \\ 2 Laboratory for Marine Mineral Resources, Qingdao National Laboratory for Marine Science and Technology, \\ Qingdao 266071, China \\ 3 College of Marine Science, University of Chinese Academy of Sciences, Beijing 100049, China \\ 4 Center for Ocean Mega-Science, Chinese Academy of Sciences, Qingdao 266071, China \\ * Correspondence: zgzeng@qdio.ac.cn
}

Citation: Zeng, Z.; Li, X.; Zhang, Y.; Qi, H. Lithium, Oxygen and Magnesium Isotope Systematics of Volcanic Rocks in the Okinawa Trough: Implications for Plate Subduction Studies. J. Mar. Sci. Eng 2022, 10, 40. https://doi.org/ 10.3390/jmse10010040

Academic Editor: Anabela Oliveira

Received: 14 November 2021

Accepted: 14 December 2021

Published: 31 December 2021

Publisher's Note: MDPI stays neutral with regard to jurisdictional claims in published maps and institutional affiliations.

Copyright: (C) 2021 by the authors. Licensee MDPI, Basel, Switzerland. This article is an open access article distributed under the terms and conditions of the Creative Commons Attribution (CC BY) license (https:// creativecommons.org/licenses/by/ $4.0 /)$.

\begin{abstract}
Determining the influence of subduction input on back-arc basin magmatism is important for understanding material transfer and circulation in subduction zones. Although the mantle source of Okinawa Trough (OT) magmas is widely accepted to be modified by subducted components, the role of slab-derived fluids is poorly defined. Here, major element, trace element, and $\mathrm{Li}, \mathrm{O}$ and $\mathrm{Mg}$ isotopic compositions of volcanic lavas from the middle OT (MOT) and southern OT (SOT) were analyzed. Compared with the MOT volcanic lavas, the T9-1 basaltic andesite from the SOT exhibited positive $\mathrm{Pb}$ anomalies, significantly lower $\mathrm{Nd} / \mathrm{Pb}$ and $\mathrm{Ce} / \mathrm{Pb}$ ratios, and higher $\mathrm{Ba} / \mathrm{La}$ ratios, indicating that subducted sedimentary components affected SOT magma compositions. The $\delta^{7} \mathrm{Li}, \delta^{18} \mathrm{O}$, and $\delta^{26} \mathrm{Mg}$ values of the SOT basaltic andesite ( $-5.05 \%$ o to $4.98 \%$, $4.83 \%$ o to $5.80 \%$ o and $-0.16 \%$ o to $-0.09 \%$, respectively) differed from those of MOT volcanic lavas. Hence, the effect of the Philippine Sea Plate subduction component, (low $\delta^{7} \mathrm{Li}$ and $\delta^{18} \mathrm{O}$ and high $\delta^{26} \mathrm{Mg}$ ) on magmas in the SOT was clearer than that in the MOT. This contrast likely appears because the amounts of fluids and/or melts derived from altered oceanic crust (AOC, lower $\delta^{18} \mathrm{O}$ ) and/or subducted sediment (lower $\delta^{7} \mathrm{Li}$, higher $\delta^{18} \mathrm{O}$ and $\delta^{26} \mathrm{Mg}$ ) injected into magmas in the SOT are larger than those in the MOT and because the injection ratio between subducted AOC and sediment is always $>1$ in the OT. The distance between the subducting slab and overlying magma may play a significant role in controlling the differences in subduction components injected into magmas between the MOT and SOT.
\end{abstract}

Keywords: Li-O-Mg isotopes; magma; plate subduction; Okinawa Trough; western Pacific

\section{Introduction}

The Okinawa Trough is a young back-arc basin in the western Pacific, and its magmas have been affected by the subducted Philippine Sea plate (PSP) [1]. The chemical and stable isotope ( $\mathrm{Li}, \mathrm{O}$, and $\mathrm{Mg}$ ) compositions of back-arc volcanic lavas are conventionally used to study the contributions of subducted slabs to magmas [1-11]. However, magmas produced by plate subduction are relatively enriched in large ion lithophile elements and light rare earth elements, but are depleted in high field strength elements; these magmas usually have low $\mathrm{Ce} / \mathrm{Pb}$ ratios since $\mathrm{Pb}$ is preferentially extracted from subducted oceanic crust and/or sediments during plate subduction and dehydration processes [8-10,12]. As incompatible elements share similar partition coefficients in magmas, their ratios are rarely modified by the partial melting or crystallization processes. Thus, the incompatible element ratios can be used to trace the compositions of mantle sources. For example, Ba/La ratio is a good indicator of subduction components [13]. $\mathrm{Ce} / \mathrm{Pb}$ ratios of sediments exhibit a distinctive range, below the values in mantle rocks, and are not significantly affected by 
fractional crystallization and partial melting processes [14]; thus, these ratios can be used to estimate the contributions of plate subduction components. Th concentrations of marine sediments are higher than the mantle values, and Th is fluid immobile relative to large ion lithophile elements. A high $\mathrm{Th} / \mathrm{Rb}$ ratio in magma indicates that a sediment melt was added to the magma source [15]. In addition, high $\mathrm{Th} / \mathrm{La}, \mathrm{Th} / \mathrm{Nb}$, and $\mathrm{Th} / \mathrm{Nd}$ ratios of the volcanic rocks indicate the contribution of sediment melts to the mantle wedge [16-19]. $\mathrm{Ba} / \mathrm{La}, \mathrm{Cs} / \mathrm{La}, \mathrm{B} / \mathrm{Nb}, \mathrm{Pb} / \mathrm{Ce}, \mathrm{B} / \mathrm{La}$, and $\mathrm{Li} / \mathrm{Y}$ ratios can also serve as proxies for fluids dehydrated from subducted sediments [20].

Moreover, lithium ( $\mathrm{Li}$ ) is a fluid mobile element, and considerable $\mathrm{Li}$ isotope fractionation occurs during oceanic crust alteration and plate subduction [21-24]. Subducted sediments and altered oceanic crust (AOC) have high Li contents (up to $80 \mathrm{ppm}$ ) and a broad range of $\delta^{7} \mathrm{Li}$ values $(-12 \%$ to $+21 \%$ ) [4,25-28]. During the metamorphism and dehydration of subducted slabs, fluids carrying heavy Li isotopes are released from the AOC and metasomatize the overlying mantle, resulting in a high- $\delta^{7} \mathrm{Li}$ mantle wedge and a low- $\delta^{7} \mathrm{Li}$ residual plate [29-31]. However, Guo, et al. [1] studied Li isotope data from middle Okinawa Trough (MOT) volcanic lavas and found that the MOT magmas were affected by subduction components (with AOC:sediment $=96: 4$ ). The $\delta^{7} \mathrm{Li}$ values of volcanic lavas from the Izu Arc in Japan vary across the arc, decreasing with increasing depth to the subducting plate, indicating that the amount of slab fluids decreases with increasing depth [32-34]. Furthermore, Benton, et al. [35] analyzed the Li isotope compositions of volcanic lavas in the Mariana Arc front seamounts and found that they have heterogeneous $\delta^{7} \mathrm{Li}$ signatures, which reflect a complex history of exchange between the slab fluids and the forearc mantle. These results indicate that there may be uncertainties in using Li isotope data for back-arc volcanic lavas to uncover magma sources and plate subduction and implies that other isotopic tools should be used to clarify magmatic processes in western Pacific plate subduction zones.

However, the oxygen $(\mathrm{O})$ isotopic compositions of the MOT volcanic lavas reveal that the magma source is mantle peridotites modified by subducted slab components [36]. The O isotopic compositions of volcanic glasses obtained from the Manus Basin and the Mariana Trough indicate that the Mariana Trough magma was affected by subduction-modified mantle [37] and that the Manus Basin magma had a $\delta^{18} \mathrm{O}$-depleted mantle reservoir, wherein $\delta^{18} \mathrm{O}$ was increased by recent subduction and a sediment component with low $\delta^{18} \mathrm{O}$ and high ${ }^{3} \mathrm{He} /{ }^{4} \mathrm{He}$ values was derived from the Manus Basin plume [37]. Moreover, the $\mathrm{O}$ isotope compositions of volcanic glasses and phenocrysts from the Lau Basin suggest that a subduction cycle involving oxygen-rich mantle materials altered the original $\delta^{18} \mathrm{O}$ of the magma [38]. All these results indicate that the $\mathrm{O}$ isotope data for volcanic lavas may not completely reflect plate subduction processes.

Magnesium (Mg) isotopes are important geochemical tracers of both magmatic sources containing recycled crustal materials [39-41] and sources of fluids dehydrated from hydrous minerals in subducting plate [5,40,42-44]. However, the Mg isotope compositions of white schist in the western Alps reveal that the dehydration of serpentinites formed in the mantle wedge during plate subduction and exhumation can release Mg-rich fluids to the subduction channel [5]. Furthermore, a study of the $\mathrm{Mg}$ isotope compositions of prograde metamorphic rocks from eastern China revealed that $\mathrm{Mg}$ isotope fractionation was limited during continental subduction [41]. All these results also indicate that the $\mathrm{Mg}$ isotope data for volcanic lavas may not completely determine magma sources and plate subduction processes.

Therefore, we sought to combine the $\mathrm{Li}$ isotope composition of volcanic lavas with their $\mathrm{O}$ and $\mathrm{Mg}$ isotope compositions to understand the magmatic processes involved in forming volcanic lavas and the influence of plate subduction on magmas in the Okinawa Trough (OT). However, previous studies have shown that subducted sediments significantly influence the mantle source of magmas beneath the OT [2,10,19,45,46]. Although slabderived fluids are also considered to contribute to the OT magmas [47-50], the evidence for this contribution is insufficient. Furthermore, $\mathrm{Li}$ and $\mathrm{O}$ isotope studies have been conducted 
in the OT, but the data remain limited to only three Li isotope analyses in the MOT. O isotope studies have primarily focused on crustal contamination as a source of magma formation [36,51-53], and the study of the $\mathrm{Mg}$ isotopic compositions of volcanic lavas has not yet been applied to the OT. Here, we investigate the major and trace elements as well as the $\mathrm{Sr}, \mathrm{Nd}, \mathrm{Li}, \mathrm{O}$, and $\mathrm{Mg}$ isotopic compositions of volcanic lavas from the MOT and SOT, with the goal of establishing how OT volcanic lavas form and what they represent for understanding the effects of subduction components on back-arc magmas.

\section{Geologic Setting}

The OT is a young back-arc basin developed in response to the subduction of the PSP (Figure 1) [11,54-56] and provides a window into understanding the influences of plate subduction on the back-arc basin evolution, mantle melting, crust-mantle interactions, and seafloor hydrothermal activity $[1,11,46,57,58]$. According to the prevailing tectonics, the OT can be divided into three parts: northern OT (NOT), MOT, and SOT, bounded by the Tokara Fault and the Kerama Fault, respectively $[1,11,50]$. The crustal thicknesses of the NOT, MOT, and SOT segments are 15 to $23 \mathrm{~km}, 12$ to $18 \mathrm{~km}$, and 10 to $16 \mathrm{~km}$, respectively [54,59-64]. The depths to the Mohorovičić discontinuity (Moho) are $27-30 \mathrm{~km}$ and $16-22 \mathrm{~km}$ in the NOT and SOT, respectively $[59,65,66]$. The subduction direction of PSP is nearly perpendicular to the axis of the MOT, with a slab depth of 150-200 km, and becomes progressively more oblique to the south, with a slab depth of $\sim 150 \mathrm{~km}[11,47,50,67,68]$. The subduction rates of PSP increase from 4.9 to $7.3 \mathrm{~cm} / \mathrm{a}$ from north to south [11,56]. In addition, the convergence rate gradually increases from $\sim 6-7 \mathrm{~cm} / \mathrm{a}$ in central Ryukyu to $\sim 7-13 \mathrm{~cm} / \mathrm{a}$ in southern Ryukyu [11,56,69], and the back-arc extension rate increases from $2 \mathrm{~cm} / \mathrm{a}$ in the NOT to $5 \mathrm{~cm} / \mathrm{a}$ in the SOT $[65,69,70]$.

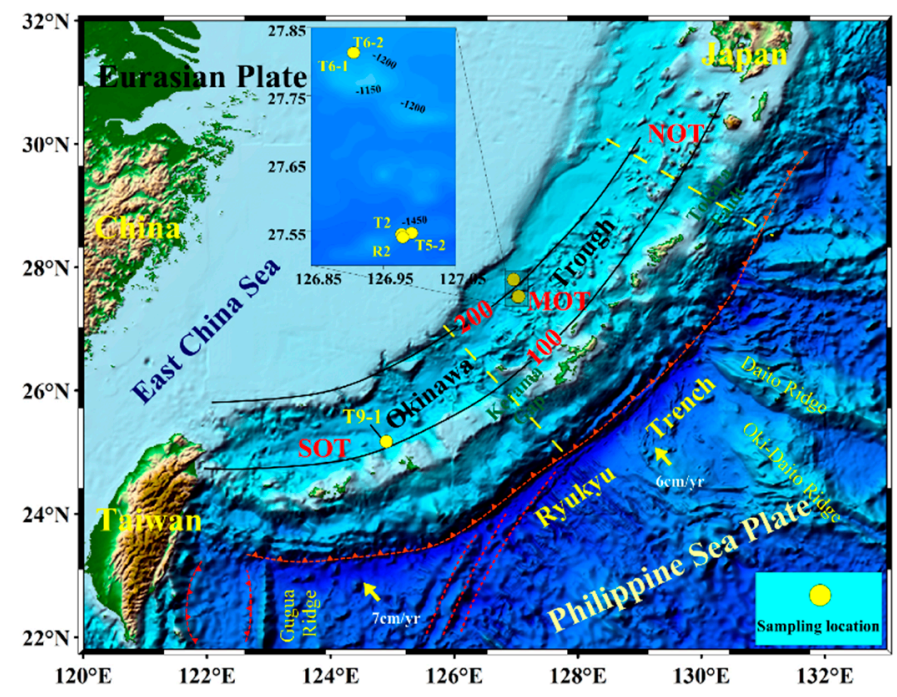

Figure 1. Regional geologic map of the Okinawa Trough (OT) showing the sampling locations. MOT, middle Okinawa Trough; SOT, southern Okinawa Trough; and NOT, northern Okinawa Trough. Black solid lines represent the depth contours of the subducting plate (Wadati-Benioff zone) [11,67,71]. Yellow dotted lines mark the Tokara Fault and the Kerama Fault.

The OT has undergone substantial magmatic activity that has generated abundant volcanic lavas. The NOT is dominated by rhyolites and dacites [6,53]. The magma in the NOT could be generated by the differentiation of basaltic melt contaminated by an enriched crustal component [53]. The MOT volcanic lavas exhibit bimodal compositional distribution, forming a basaltic-rhyolitic dominant suite with scarce andesitic lavas [6,72,73]. The $\mathrm{Sr}-\mathrm{Nd}-\mathrm{Pb}$ isotope compositions suggest that the magma source of the MOT volcanic lavas resembles the depleted mantle (DM) but also shows signatures of the enriched mantle II (EMII), indicating that the mantle source for the MOT volcanic lavas is a hybrid of the DM 
and EMII endmembers [74]. Geochemical modelling shows that the magma source for the MOT volcanic lavas could be generated by hybridizing approximately $0.8-2.0 \%$ subducted sediments with 98.0-99.2\% mantle rocks [74]. The SOT is dominated by rhyolites, basalts and basaltic andesites $[50,72,75,76]$. In the SOT, the petrogenesis of rhyolites is due to the ascent of basaltic magma from a deep magma reservoir to a shallow depth where fractional crystallization and crustal assimilation occurred [75]. The decrease in the DUPAL-like anomaly from the rhyolites sampled in the western part of the MOT to the volcanic lavas in the MOT axial zone can be explained by the injection of asthenospheric mantle into the pre-existing mantle with DUPAL-like signature during back-arc extension. The Tl-Pb-Sr-Nd isotopic compositions of volcanic lavas from the NOT to the SOT can be accounted for by the sediment inputs of $<1 \%, 0.1-1 \%$ and $0.3-2 \%$, respectively, by weight to the depleted mantle source [46]. The magma sources of the SOT basalts are mainly affected by slab fluids and bulk sediments [47]. The magma sources of the MOT basalts are affected by fluids derived from both sediment and AOC [47]. Based on the above findings, we aim to use the geochemical and $\mathrm{Li}-\mathrm{O}-\mathrm{Mg}$ isotope compositions of OT volcanic lavas to understand the origins of magmas and the effects of plate subduction on magmas in this study.

\section{Sampling and Methods}

\subsection{Sample Collection}

The volcanic lavas were collected from the MOT and SOT using a TV grab sampler in 2014 and 2016 during HOBAB (Hello Back Arc Basin) 2 and 4 cruises, respectively. The R2, T5-2, and T2 samples were obtained from the Iheya Ridge (MOT), samples T6-1 and T6-2 were obtained from the western slope of the Iheya Ridge in the MOT, and sample T9-1 was obtained from the Yaeyama Graben (SOT) (Table S1 and Figure 1).

T9-1 basaltic andesite from the SOT is a black vesicular lava sample with a compact, massive structure. It contains few phenocrysts, which predominantly consist of clinopyroxene $(\sim 5 \%)$, orthopyroxene $(\sim 5 \%)$, plagioclase $(\sim 10 \%)$, a small amount of olivine $(\sim 1 \%)$, and accessory minerals (magnetite and ilmenite). The groundmass of the T9-1 basaltic andesite is mostly composed of plagioclase and clinopyroxene microlites (Figure 2a). The phenocrysts in the T9-1 basaltic andesite are euhedral to subhedral and range from $\sim 0.1$ to $\sim 1.0 \mathrm{~mm}$ in size.

$\mathrm{R} 2$ basalt from the MOT is a black lava with a moderately porphyritic massive structure. It contains olivine $(\sim 5 \%)$, plagioclase $(\sim 5 \%)$, and clinopyroxene $(\sim 1 \%)$ phenocrysts. The phenocrysts in the R2 basalt are euhedral to subhedral, with sizes ranging from $\sim 0.05$ to $6 \mathrm{~mm}$. The groundmass of the R2 basalt is dominated by clinopyroxene and plagioclase microlites (Figure 2b). Both the T5-2 trachyandesite and T2 andesite from the MOT are black lavas with compact, massive structures. Thin sections reveal that the T5-2 trachyandesite and T2 andesite are porphyritic and that $\sim 15 \%$ of the phenocrysts are plagioclase with minor clinopyroxene and orthopyroxene. The phenocrysts in the T5-2 trachyandesite and T2 andesite samples are euhedral to subhedral, with sizes ranging from $\sim 40$ to $\sim 300 \mu \mathrm{m}$ (Figure 2c,d). The T6-1 pumice from the MOT (Figure 2e) is a light, white, vesicular lava. The phenocrysts $(<5 \%)$ in the T6-1 pumice are primarily clinopyroxene, orthopyroxene, and plagioclase and range from $\sim 0.2$ to $0.5 \mathrm{~mm}$ in size. The groundmass in the T6-1 pumice is mainly composed of plagioclase microlites (Figure 2e). The T6-2 pumice from the MOT is a gray-black vesicular lava. The phenocrysts $(<5 \%)$ in the T6-2 pumice mainly consist of clinopyroxene, plagioclase, and orthopyroxene, with sizes ranging from $\sim 0.2$ to $0.4 \mathrm{~mm}$ in size. The groundmass in the T6-2 pumice is also mainly composed of plagioclase microlites (Figure 2f).

Details about the sample processing, electron microprobe, major element and trace element, and $\mathrm{Sr}$ and $\mathrm{Nd}$ isotope analytic methods are given in the Supplementary Texts, and the sampling locations and sample analytic results can be found in Tables S1-S8. 


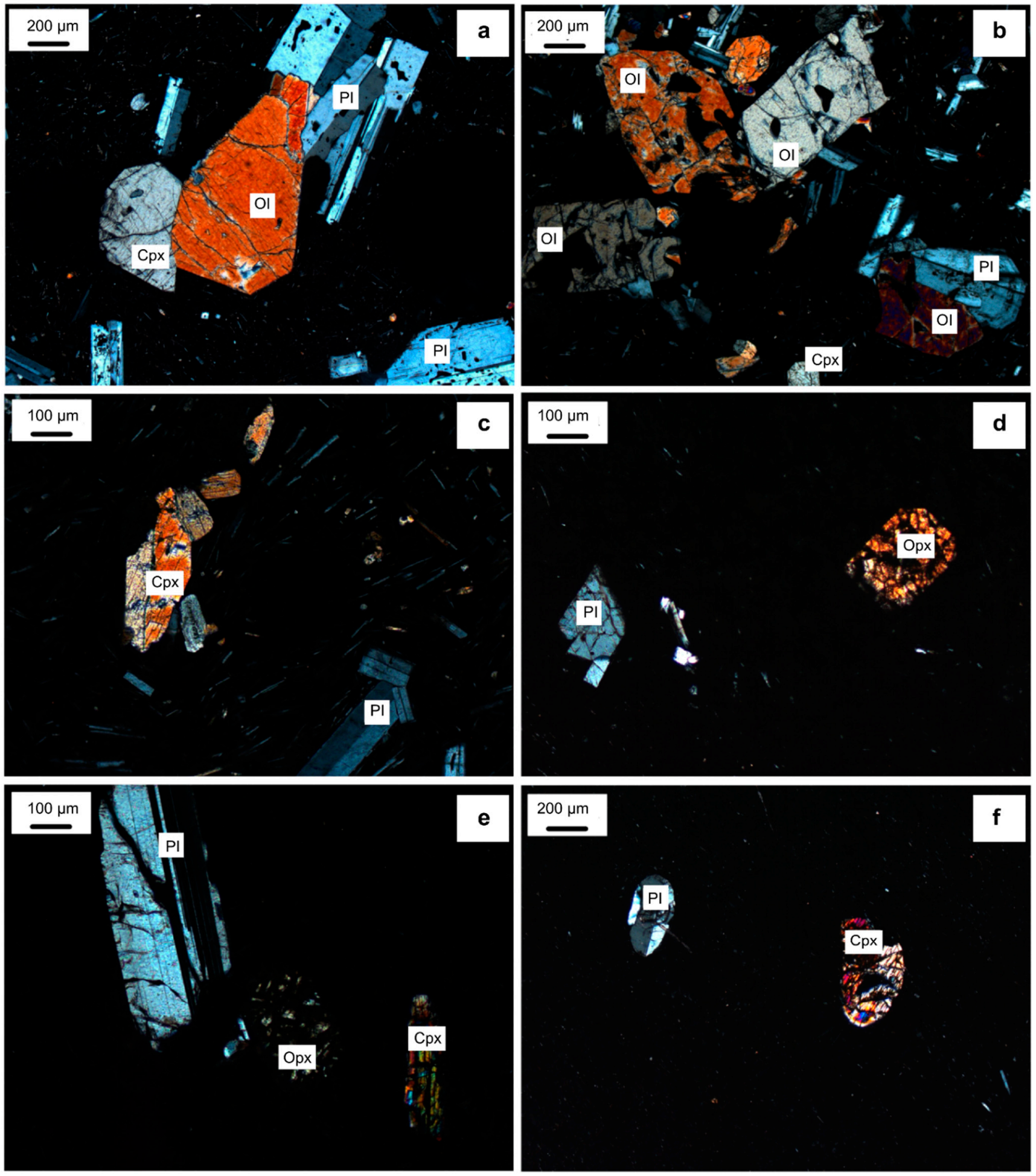

Figure 2. Representative photomicrographs of the MOT and SOT volcanic lava samples. (a) T9-1 is from the SOT and (b) R2, (c) T5-2, (d) T2, (e) T6-1, and (f) T6-2 are from the MOT. Abbreviations: olivine $(\mathrm{Ol})$; magnetite $(\mathrm{Mt})$; clinopyroxene $(\mathrm{Cpx})$; orthopyroxene $(\mathrm{Opx})$; and plagioclase $(\mathrm{Pl})$.

\section{2. $\mathrm{Li}, \mathrm{O}$, and $\mathrm{Mg}$ Isotope Analyses}

The whole-rock powders and minerals were fully digested. All reagents $\left(\mathrm{HF}, \mathrm{HNO}_{3}\right.$ and $\mathrm{HCl}$ ) were doubly distilled, and Milli- $\mathrm{Q}^{\circledR}$ water $(18.2 \mathrm{M} \Omega \cdot \mathrm{cm})$ (Merck Millipore Inc., Billerica, MA, USA) was used. For the isotopic analyses, Li was separated using organic solvent-free two-step liquid chromatography in a clean laboratory at the University of 
Science and Technology of China (USTC). The procedure used was described by [77]. All separations were monitored using inductively coupled plasma mass spectrometry (ICPMS) analysis to guarantee both a high $\mathrm{Li}$ yield ( $>99.8 \%$ recovery) and a low $\mathrm{Na} / \mathrm{Li}$ ratio $(<0.5)$. The final Li concentrations of the solutions used for the multi-collector ICP-MS (MC-ICP-MS) analyses were targeted in the range of 50-100 ppb to ensure the precision and accuracy of the results. The total procedural blanks for column chromatography alone and for sample digestion and column chromatography combined were $<\sim 0.03 \mathrm{ng}$ of $\mathrm{Li}$. Compared with the $\sim 200-5000 \mathrm{ng}$ of Li used for our analyses, the blank correction was negligible at the uncertainty levels achieved $(\leq 0.2 \%$, see below).

The lithium isotope compositions were analyzed at the USTC using a Neptune Plus MC-ICP-MS system (Thermo Fisher Scientific Inc., Waltham, MA, USA) operating in wet plasma mode using an X skimmer cone and jet sample cones (Table S9). The samples were introduced through a low-flow PFA nebulizer $(\sim 50 \mu \mathrm{L} / \mathrm{min})$ coupled with a quartz spray chamber. The ${ }^{7} \mathrm{Li}$ and ${ }^{6} \mathrm{Li}$ isotopes were measured simultaneously by two opposing Faraday cups. Each sample analysis was bracketed before and after by analyses of the reference material L-SVEC. For a solution containing $100 \mathrm{ppb}$ of $\mathrm{Li}$ and an uptake rate of $50 \mu \mathrm{L} / \mathrm{min}$, the typical ${ }^{7} \mathrm{Li}$ intensity was $\sim 8 \mathrm{~V}$. The in-run precision of the ${ }^{7} \mathrm{Li} /{ }^{6} \mathrm{Li}$ measurements was $\leq 0.2 \%$ for one block of 60 ratios. The external precision was based on the long-term analysis of an in-house standard (Li-QCUSTC $=+8.8 \% \pm 0.2 \%$ ( 2 standard deviations (SD), $n=161)$ ). For international rock standards, repeat analyses at the USTC yielded values of $+4.4 \%$ o $\pm 0.3 \%$ o (2SD, $n=8)$ for BHVO-2, $-0.8 \% \pm 0.3 \%$ o $(2 \mathrm{SD}, n=29)$ for GSP-2, and $+5.9 \% \pm 0.5 \%$ o (2SD, $n=9)$ for AGV-1, which were within the uncertainty limits of previously published results $[77,78]$. The results are reported in the delta notation $\left[\delta^{7} \mathrm{Li}=\left(\left({ }^{7} \mathrm{Li} /{ }^{6} \mathrm{Li}\right)_{\text {sample }} /\left({ }^{7} \mathrm{Li} /{ }^{6} \mathrm{Li}\right)_{\text {standard }}-1\right) \times 1000\right]$ relative to the $\mathrm{L}-\mathrm{SVEC} \mathrm{Li}$ isotope standard [79].

The whole-rock and mineral oxygen isotope compositions were measured using laser fluorination with a $25 \mathrm{~W}$ MIR-10 carbon dioxide $\left(\mathrm{CO}_{2}\right)$ laser at the CAS Key Laboratory of Crust-Mantle Materials and Environments at the USTC, Hefei. The oxygen isotope analyses and the data acquisition followed the methods described by $[80,81] . \mathrm{O}_{2}$ was extracted from the samples through reaction with bromine pentafluoride $\left(\mathrm{BrF}_{5}\right)$ in nickel (Ni) bombs, and it was then converted to $\mathrm{CO}_{2}$ through reaction with a hot carbon rod. The $\delta^{18} \mathrm{O}$ of $\mathrm{CO}_{2}$ was measured using a Delta+ mass spectrometer. Reference minerals GBW04409 quartz $\left(\delta^{18} \mathrm{O}=11.11 \%\right.$ o $\pm 0.1 \%$ ) [81] and in-house standard 04BXL07 garnet $\left(\delta^{18} \mathrm{O}_{\mathrm{V}-\mathrm{SMOW}}=3.70 \% \pm 0.1 \%\right.$ ) [82] were analyzed during each run. We analyzed the $\mathrm{O}$ isotope compositions of the whole rocks and the minerals from each sample twice, except for R2-2-Cpx and T2-Opx (Table S9). The data are reported using the usual $\delta^{18} \mathrm{O}$ notation relative to Vienna standard mean ocean water (V-SMOW). On a given day, the reproducibility of each standard was better than $\pm 0.2 \%$ o $(2 \sigma)$ for $\delta^{18} \mathrm{O}$.

The Mg isotopes were measured using a Thermo Scientific Neptune Plus MC-ICP-MS system following the methods of [83] at the CAS Laboratory of Crust-Mantle Materials and Environments at the USTC, Hefei. The whole-rock powders and minerals were fully digested to obtain $\sim 20 \mu \mathrm{g}$ of $\mathrm{Mg}$ for chemical purification. A mixture of concentrated $\mathrm{HF}-\mathrm{HNO}_{3}$ was used for digestion. $\mathrm{Mg}$ was purified in Savillex columns loaded with $2 \mathrm{~mL}$ of Bio-Rad $\mathrm{AG}^{\circledR} 50 \mathrm{~W}-\mathrm{X} 12$ resin (Bio-Rad Laboratories Inc., Hercules, CA, USA). For the $\mathrm{Mg}$ isotope analyses, sample-standard bracketing was used, wherein DSM-3 was the bracketing standard. The $\mathrm{Mg}$ isotope compositions are reported using the standard $\delta$ notation relative to DSM-3. The uncertainties in the $\delta^{25} \mathrm{Mg}$ and $\delta^{26} \mathrm{Mg}$ values of the standards and the samples are reported as 2SD based on repeated measurements (Table S9). The data quality was carefully controlled through the repeated analysis of multiple $\mathrm{Mg}$ isotope standards (Table S9). The long-term external precision was better than $\pm 0.05 \%$. Furthermore, each sample was processed three times under the same conditions. During the analyses, the $\delta^{26} \mathrm{Mg}$ values obtained for BCR-2 $(-0.215 \% \pm 0.017 \% ; n=3)$ and BHVO-2 $(-0.205 \%$ o $\pm 0.020 \% ; n=3)$ were all identical within the established uncertainty limits $(-0.162 \%$ o $\pm 0.014 \%$ for BCR-2 and $-0.216 \%$ o $\pm .035 \%$ for BHVO-2) [83]. 


\section{Results}

\subsection{Clinopyroxene and Orthopyroxene}

The clinopyroxene contents in R2 basalt, the orthopyroxene contents in T5-2 trachyandesite, T2 andesite, T6-1 and T6-2 rhyolites from the MOT, and the orthopyroxene content in T9-1 basaltic andesite from the SOT, were analyzed using an electron microprobe. The data are presented in Tables S2-S6. The clinopyroxene and orthopyroxene were unzoned, and their compositions were homogeneous (Figure 2 and Tables S2-S6). There was no notable difference between the Mg\#s of clinopyroxene and orthopyroxene [80-84 in R2 $(n=11)$, $67-76$ in T9-1 $(n=18), 59-72$ in T2 $(n=14), 34-48$ in T6-1 $(n=29)$, and 47-52 in T6-2 $(n=6)]$ (Tables S2-S6).

However, assuming that the mineral phases represent equilibrium compositions, the OT clinopyroxene and orthopyroxene composition data (Tables S2-S6) allowed the use of the clinopyroxene and orthopyroxene-liquid geothermobarometer of $[84,85]$ to calculate the crystallization temperatures and pressures of the magma along its ascent path. The standard errors of the temperature and pressure calibrations were $39{ }^{\circ} \mathrm{C}$ and $2.1 \mathrm{kbar}$, respectively [85]. According to the clinopyroxene-liquid geothermobarometer (Table S4) [84], the crystallization temperature, pressure, and magma depth for formation of the clinopyroxene phenocrysts in the $\mathrm{R} 2$ basalt from the MOT were estimated to be in the ranges of $1112-1137{ }^{\circ} \mathrm{C}, 0.14-0.42 \mathrm{GPa}$, and $\sim 8.0-16.9 \mathrm{~km}$, respectively. From the orthopyroxeneliquid geothermobarometers (Table S3) [85], the crystallization temperature, pressure, and magma depth for formation of the orthopyroxene phenocrysts in the T2 andesite from the MOT were calculated to be in the ranges of $1021-1095{ }^{\circ} \mathrm{C}, 0.03-0.37 \mathrm{GPa}$, and $4.3-15.3 \mathrm{~km}$, respectively (Table S3). The crystallization temperature, pressure, and magma depth for formation of the orthopyroxene phenocrysts in the T6-1 and T6-2 rhyolites from the MOT were estimated to be $821-884^{\circ} \mathrm{C}$ and $844-858^{\circ} \mathrm{C}, 0.11-0.59 \mathrm{GPa}$ and $0.01-0.11 \mathrm{GPa}$, and 7.1-22.2 km and 3.7-7.1 km, respectively (Tables S5 and S6). The crystallization temperature, pressure, and magma source depth for forming the orthopyroxene phenocrysts in the T9-1 basaltic andesite from the SOT were estimated to be $1095-1138{ }^{\circ} \mathrm{C}, 0.16-0.40 \mathrm{GPa}$, and 8.4-16.1 km, respectively (Table S2).

\subsection{Major Element and Trace Element Compositions of the Volcanic Lavas}

The major element concentrations of the volcanic lavas obtained from the MOT and SOT are presented in Table S7. No increase in ${ }^{87} \mathrm{Sr} /{ }^{86} \mathrm{Sr}$ ratios was observed with increasing LOI (Figure S1), indicating that the samples were free of seawater alteration. On the total alkalis-silica (TAS) diagram, the volcanic lavas plot in the R2 basalt, T9-1 basaltic andesite, T5-2 trachyandesite, T2 andesite, T6-1 and T6-2 rhyolite fields, indicate they can be classified as subalkaline $\left(\mathrm{SiO}_{2}=51.62-73.85\right.$ wt. $\% ; \mathrm{Na}_{2} \mathrm{O}+\mathrm{K}_{2} \mathrm{O}=2.63-8.16$ wt. $\left.\%\right)$ (Figure 3) [86-88]. On the $\mathrm{K}_{2} \mathrm{O}$ vs. $\mathrm{SiO}_{2}$ diagram, the T9-1 basaltic andesite from the SOT and the R2 basalt from the MOT plot in the low-K arc tholeiitic field, the T5-2 trachyandesite and T2 andesite from the MOT plot in the medium-K calc-alkaline field, and the T6-1 and T6-2 rhyolites from the MOT, are in the high-K calc-alkaline field (Figure 3). On the Harker diagrams (Figure S2), the major element oxides (except for $\mathrm{Na}_{2} \mathrm{O}, \mathrm{TiO}_{2}$, and $\mathrm{P}_{2} \mathrm{O}_{5}$ ) of the MOT volcanic lavas exhibit first-order trends, indicating that they evolved through the fractional crystallization of magma [89]. In addition, the T9-1 basaltic andesite from the SOT had lower $\mathrm{Na}_{2} \mathrm{O}$ (2.20 wt.\%) and higher $\mathrm{Al}_{2} \mathrm{O}_{3}$ (18.55 wt.\%) contents than the MOT volcanic lavas $\left(\mathrm{Na}_{2} \mathrm{O}=2.77-5.43\right.$ wt. $\%, \mathrm{Al}_{2} \mathrm{O}_{3}=12.23-17.08$ wt.\%) (Figure S2).

The trace element concentrations of the OT lava samples are presented in Table S8. The primitive mantle-normalized spider diagrams for the MOT and SOT volcanic lavas reveal obvious enrichment in large ion lithophile elements relative to the high field strength elements and rare earth elements (Figure 4). All the samples had negative niobium $(\mathrm{Nb})$, tantalum (Ta), and titanium (Ti) anomalies and distinctly positive $\mathrm{Pb}$ anomalies (Figure 4). Moreover, the MOT rhyolites exhibited significant Sr, P, and Ti depletions (Figure 4e,f), suggesting mineral fractionation. The R2 basalt from the MOT and the T9-1 basaltic andesite from the SOT had slight Sr enrichments (Figure 4a). The chondrite-normalized REE diagrams of the 
MOT and SOT volcanic lavas reveal light REE (LREE) enrichment relative to heavy REEs (HREEs) (Figure 4), and the MOT volcanic lava samples $\left((\mathrm{La} / \mathrm{Yb})_{\mathrm{N}}=2.23-3.68\right)$ were more fractionated than the T9-1 basaltic andesite sample $\left((\mathrm{La} / \mathrm{Yb})_{\mathrm{N}}=1.66\right)$ from the SOT. The MOT rhyolites exhibited significant negative europium $(\mathrm{Eu})$ anomalies $\left(\mathrm{Eu} / \mathrm{Eu}^{*} \mathrm{T6}-1=0.55\right.$, and $\mathrm{Eu} / \mathrm{Eu}^{*} \mathrm{T6}-2=0.36$, where $\left.\mathrm{Eu} / \mathrm{Eu}^{*}=2 \mathrm{Eu}_{\mathrm{N}} /\left(\mathrm{Sm}_{\mathrm{N}}+\mathrm{Gd}_{\mathrm{N}}\right)\right)$, the MOT trachyandesite and andesite exhibited small negative $\mathrm{Eu}$ anomalies $\left(\mathrm{Eu} / \mathrm{Eu}^{*} \mathrm{T5}-2=0.85\right.$, and $\left.\mathrm{Eu} / \mathrm{Eu}^{*} \mathrm{~T} 2=0.86\right)$, and the MOT basalt and the SOT basaltic andesite exhibited negligible Eu anomalies $\left(\mathrm{Eu} / \mathrm{Eu}^{*}{ }_{\mathrm{R} 2}=0.99\right.$, and $\left.\mathrm{Eu} / \mathrm{Eu}^{*}{ }_{\mathrm{T} 9-1}=1.05\right)$. However, fractionation between the LREEs and HREEs was higher in the MOT volcanic lavas $\left((\mathrm{La} / \mathrm{Yb})_{\mathrm{N}}=2.23-3.68\right)$ than in the SOT lava $\left((\mathrm{La} / \mathrm{Yb})_{\mathrm{N}}=1.66\right)$.

a

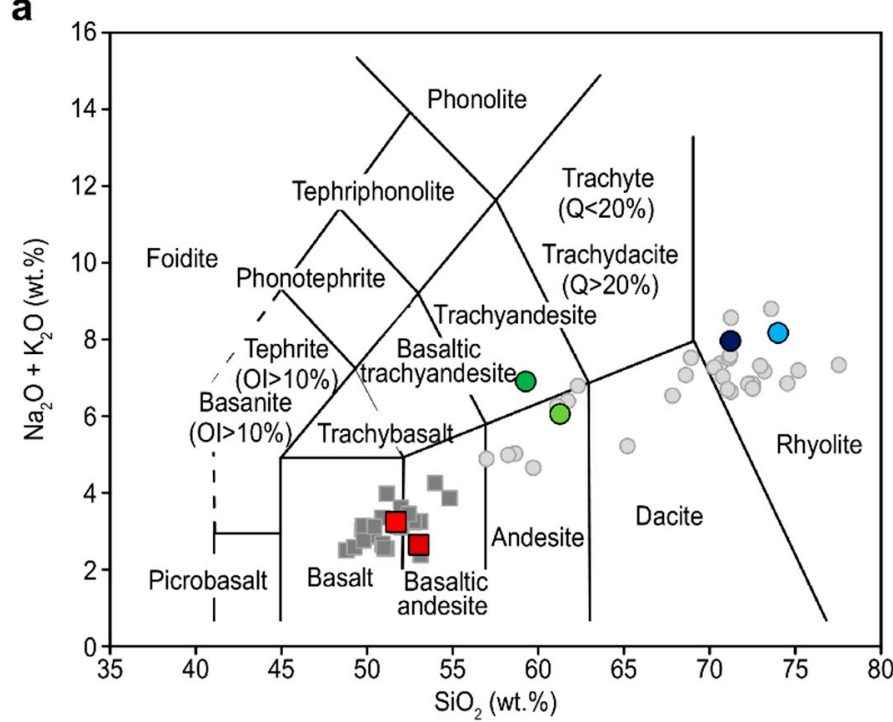

b

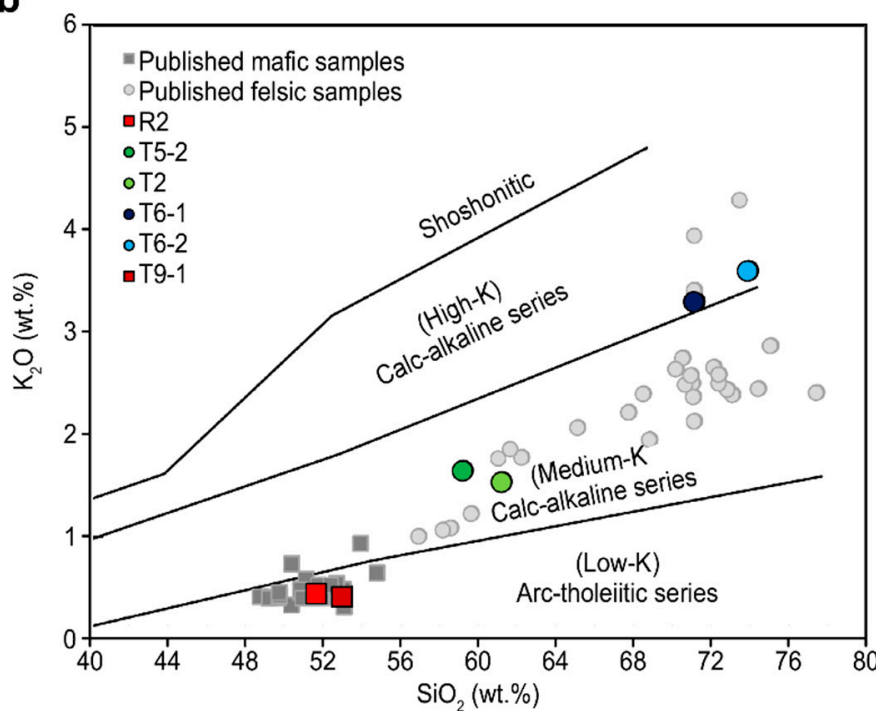

Figure 3. Classification diagrams for the MOT and SOT volcanic lavas. (a) Plots of $\mathrm{Na}_{2} \mathrm{O}+\mathrm{K}_{2} \mathrm{O}$ vs. $\mathrm{SiO}_{2}$. The base diagram is from [87], and the boundary between the alkaline and subalkaline rocks is from [86]. (b) $\mathrm{K}_{2} \mathrm{O}$ (wt.\%) vs. $\mathrm{SiO}_{2}$ (wt.\%). Boundaries are from [88]. Data for published mafic samples are from $[1,36,50,74]$. Data for published felsic samples from [1,73,74]. Data for samples R2, T5-2, T6-1, T2, T6-2, and T9-1 are from this study.

\subsection{Li-O-Mg Isotope Compositions of the Volcanic Lavas and Minerals}

The $\mathrm{Li}$ isotopic compositions of the OT volcanic lavas and minerals are reported in Table S9 and are plotted in Figure 5a,b. The $\delta^{7} \mathrm{Li}$ values of all samples vary from $-5.05 \%$ to $+5.61 \%$ (Figure $5 \mathrm{a}$ ). The highly fractionated rhyolites (T6-1 and T6-2) have higher $\delta^{7} \mathrm{Li}$ values than the mafic and intermediate lavas (Figure S3b), probably as a result of late-stage magma evolution; thus, these data are not included in the following discussion. The T5-2 trachyandesite from the MOT had lower $\delta^{7} \mathrm{Li}$ values $(-0.83 \%$ to $+2.90 \%$ ) than the other MOT samples (Figure 5a). The majority of the $\delta^{7} \mathrm{Li}$ values in the MOT volcanic lavas fell within the range of mid-ocean ridge basalts (MORBs) $(+1.50 \%$ to $+6.85 \%$ ) (Figure 5a,b) $[22,33,91-93]$, indicating that these samples originated from similar magmatic sources. The glass in T9-1 basaltic andesite from the SOT had the highest $\delta^{7} \mathrm{Li}$ value $\left(+4.98 \%\right.$ ) (Table S9), while the $\delta^{7} \mathrm{Li}$ values of clinopyroxene $(+0.49 \%)$, orthopyroxene $(+1.04 \%)$, and plagioclase $(-5.05 \%)$ in the T9-1 basaltic andesite sample from the SOT were all lower than those of MORBs (Table S9 and Figure 5a). The $\delta^{7} \mathrm{Li}$ values of the MOT and SOT plagioclase and clinopyroxene phenocrysts were lower than those of olivine, orthopyroxene, and glass (Table S9 and Figure 5a). Furthermore, most of the $\delta^{7} \mathrm{Li}$ values obtained in this study were lower than those obtained for the MOT volcanic lavas by [1] $\left(\delta^{7} \mathrm{Li}=+2.6 \%\right.$ to $\left.+6.9 \%, n=3\right)$. The $\delta^{7} \mathrm{Li}$ values of the OT basaltic lavas $\left(\delta^{7} \mathrm{Li}_{\mathrm{R} 2-1}=+3.33 \%\right.$, and $\delta^{7} \mathrm{Li}_{9-1}=+3.45 \%$ o $)$ were lower than those reported for the Lau Basin basalts $\left(\delta^{7} \mathrm{Li}=+4.32 \%\right.$ to $+4.82 \%$ ) [4]. 

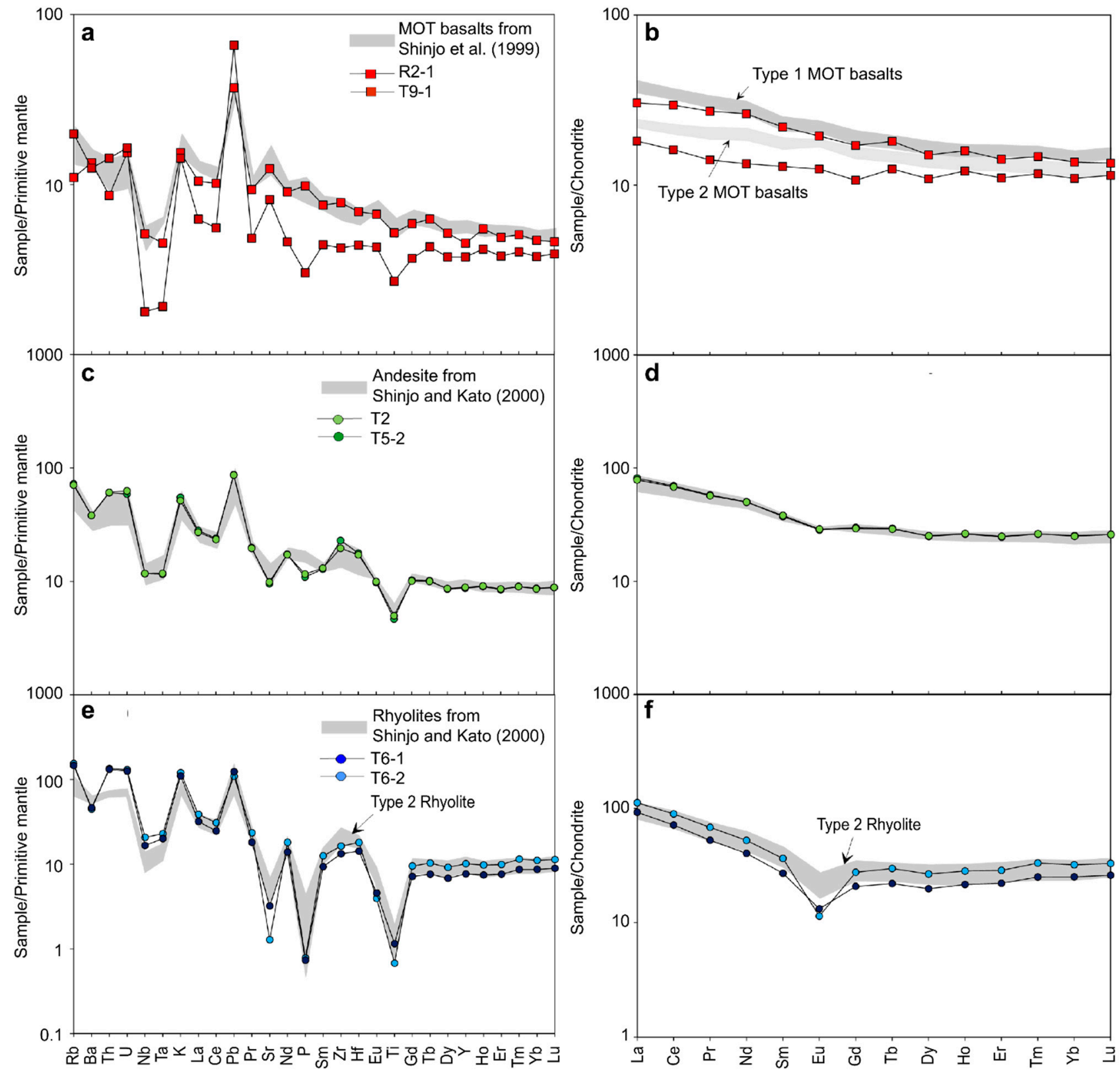

Figure 4. (a,c,e) Trace element patterns normalized to primitive mantle and $(\mathbf{b}, \mathbf{d}, \mathbf{f})$ corresponding rare earth element (REE) patterns normalized to chondritic contents for the MOT and SOT volcanic lavas. Primitive mantle and chondrite contents are from [90]. $(\mathbf{a}, \mathbf{b})$ show the trace element distributions of the MOT basalt and the SOT basaltic andesite, respectively. (c,d) show the trace element distributions of the MOT andesite and trachyandesite, respectively. $(\mathbf{e}, \mathbf{f})$ show the trace element distributions of the MOT rhyolites. Data are from [50,73], and this study.

In addition, the $\mathrm{Li}$ isotope fractionations $\left(\Delta^{7} \mathrm{Li}_{\mathrm{x}-\mathrm{y}}=\delta^{7} \mathrm{Li}_{\mathrm{x}}-\delta^{7} \mathrm{Li}_{\mathrm{y}}\right)$ between coexisting mineral phases $(x-y)$ were also calculated. The $\Delta^{7} \mathrm{Li}_{\text {cpx-ol }}$ (Li isotope fractionation between coexisting clinopyroxene and olivine) and $\Delta^{7} \mathrm{Li}_{\text {pl-ol }}(\mathrm{Li}$ isotope fractionation between coexisting plagioclase and olivine) values of the R2 basalt from the MOT were -3.76 and -3.77 , respectively. The $\Delta^{7} \mathrm{Li}_{\text {cpx-ol }}, \Delta^{7} \mathrm{Li}_{\text {opx-ol }}$, and $\Delta^{7} \mathrm{Li}_{\text {pl-ol }}$ values of the $75-2$ trachyandesite from the MOT were $-3.24,-0.07$, and -0.55 , respectively. The $\Delta^{7} \mathrm{Li}_{\text {cpx-ol }}, \Delta^{7} \mathrm{Li}_{\text {opx-ol }}$, and $\Delta^{7} \mathrm{Li}_{\text {pl-ol }}$ values of the T9-1 basaltic andesite from the SOT were $-2.35,-1.80$, and -7.88 , respectively. The $\Delta^{7} \mathrm{Li}$ values of all samples were negative. This cannot be explained by closed system equilibrium between the different minerals and olivine. 

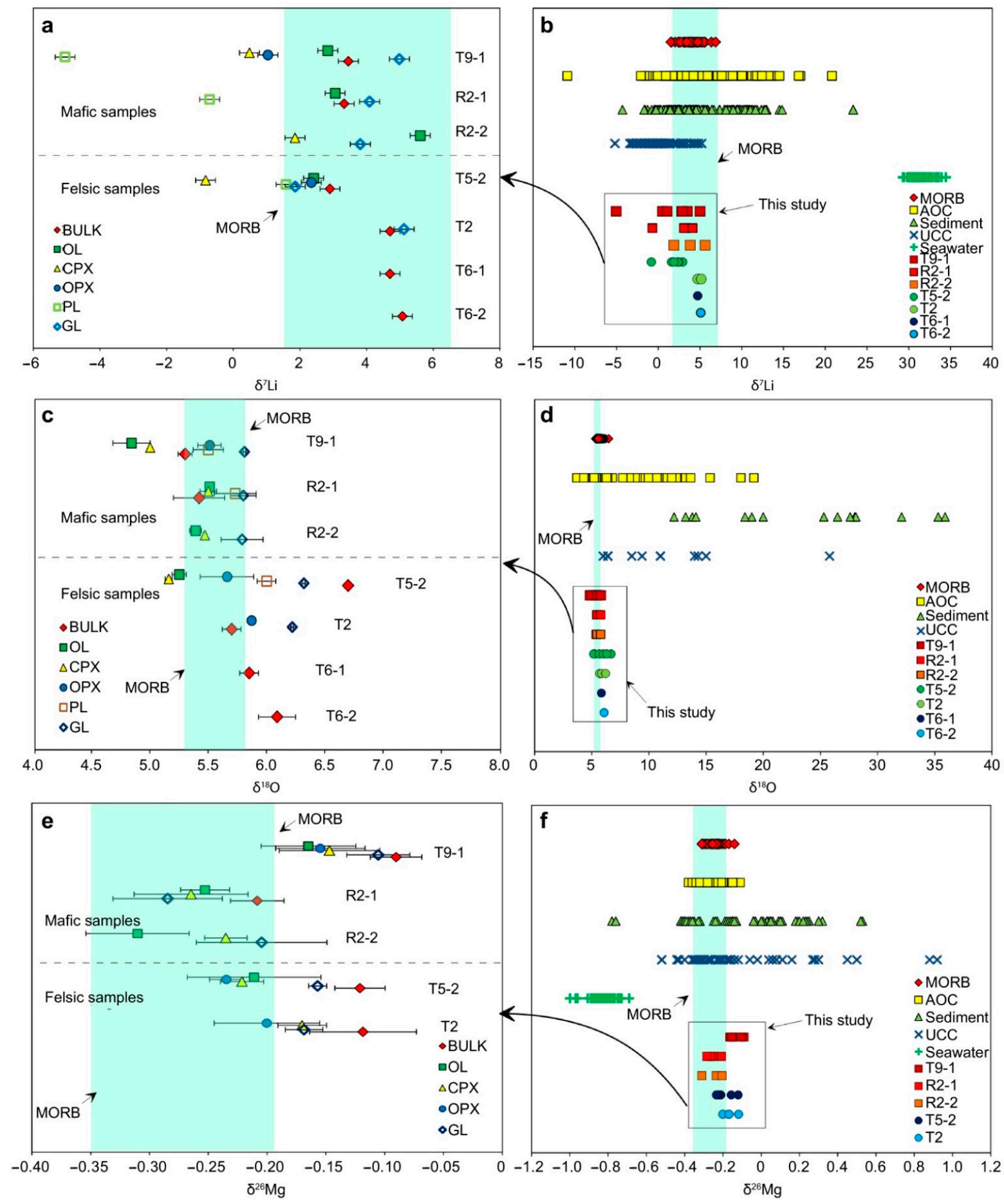

Figure 5. The $\delta^{7} \mathrm{Li}$ distributions of (a) the different whole-rock and mineral separates from the Okinawa Trough (OT) and (b) mid-ocean ridge basalts (MORBs), AOC, sediment, upper continental crust, and seawater. The $\delta^{18} \mathrm{O}$ distributions of (c) the different whole-rock and mineral separates from the OT and (d) MORBs, AOC, sediment, and upper continental crust. The $\delta^{26} \mathrm{Mg}$ distributions of (e) the different whole-rock and mineral separates from the OT and (f) MORBs, AOC, sediment, upper continental crust, and seawater. The MORB $\delta^{7} \mathrm{Li}$ range is from $[22,33,91-93]$. The AOC $\delta^{7} \mathrm{Li}$ data are from $[4,22,25,94]$. The sediment $\delta^{7} \mathrm{Li}$ data are from $[3,4,25,27,95-97]$. Upper continental crust (UCC) $\delta^{7} \mathrm{Li}$ data are from [98]. The MORB $\delta^{18} \mathrm{O}$ range is from [99-101]. AOC $\delta^{18} \mathrm{O}$ data are from [102,103]. Sediment $\delta^{18} \mathrm{O}$ data are from [104]. UCC $\delta^{18} \mathrm{O}$ data are from [105]. The MORB $\delta^{26} \mathrm{Mg}$ range is from [106,107]. AOC $\delta^{26} \mathrm{Mg}$ data are from [39]. Sediment $\delta^{26} \mathrm{Mg}$ data are from [108]. UCC $\delta^{26} \mathrm{Mg}$ data are from [109]. 
The oxygen isotopic compositions of the OT volcanic lavas and minerals varied from $+4.83 \%$ o to $+6.69 \%$ o (Table S9 and Figure $5 \mathrm{c}$ ). The $\delta^{18} \mathrm{O}$ values showed no significant increase with increasing $\mathrm{SiO}_{2}$ concentrations for whole-rock samples (Figure S3a). The $\delta^{18} \mathrm{O}$ values $(+5.38 \%$ o to $+5.79 \%$ ) of R2-1 and R2-2 basalts from the MOT fell within the MORB range (Figure $5 \mathrm{c}, \mathrm{d})\left(+5.30 \%\right.$ to $+5.80 \%$ ) $[110,111]$. The $\delta^{18} \mathrm{O}$ values of the $\mathrm{T} 5-2$ trachyandesite exhibited a broader range $(+5.15 \%$ o to $+6.69 \%$ ) than those of the other MOT samples (Figure $5 \mathrm{c}$ ). The majority of the $\delta^{18} \mathrm{O}$ values $(+4.83 \%$ to $+5.80 \%$ o $)$ of the T9-1 basaltic andesite and its mineral samples from the SOT were lower than those of the MOT volcanic lava samples $(+5.15 \%$ o to $+6.69 \%$ ) (Table S9 and Figure $5 \mathrm{c})$. Moreover, the $\delta^{18} \mathrm{O}$ values of all the OT volcanic lava and mineral samples analyzed in this study overlapped with the $\delta^{18} \mathrm{O}$ range previously reported for volcanic lavas from the Manus Basin $(+4.96 \%$ to $+6.68 \%$ ) $[37,100]$. The whole-rock $\delta^{18} \mathrm{O}$ values of T5-2 (+6.69\%o) and T6-2 (+6.08\%o fell within the range of the MOT volcanic lavas $(+6.0 \%$ o to $+7.6 \%$ ) analyzed by [36]. The $\delta^{18} \mathrm{O}$ values of the T9-1 (+5.29\%o), R2-1 (+5.41\%o), R2-2 (+5.38\%o), T2 (+5.69\%o), and T6-1 $(+5.84 \%$ o $)$ whole-rock samples (Table S9) were lower than those of the volcanic lavas $(+6.6 \%$ to $+8.8 \%$ ) analyzed by $[36,53]$. The majority of the $\delta^{18} \mathrm{O}$ values of the T9-1 basaltic andesite from the SOT and the R2-1 and R2-2 basalts from the MOT were lower than those measured for the volcanic lavas of the North Fiji Basin $\left(\delta^{18} \mathrm{O}=+5.78 \%\right.$ o to $+6.06 \%$ ) [38] and the Mariana back-arc basin $\left(\delta^{18} \mathrm{O}=+5.8 \%\right.$ o to $+6.0 \%$ o $[7]$.

In addition, the $\delta^{18} \mathrm{O}$ values of plagioclase and glass were higher than those of olivine, clinopyroxene, and orthopyroxene in the MOT and SOT volcanic lavas (Table S9), and the $\delta^{18} \mathrm{O}$ values of olivine, clinopyroxene, and orthopyroxene exhibited smaller variations than those of volcanic glass (Figure $5 \mathrm{c}$ ). The $\Delta^{18} \mathrm{O}_{\mathrm{cpx} \text {-ol }}$ and $\Delta^{18} \mathrm{O}_{\mathrm{pl} \text {-ol }}$ values calculated for the $\mathrm{R} 2$ basalt from the MOT were 0.08 and 0.22 , respectively. The $\Delta^{18} \mathrm{O}_{\text {cpx-ol }}, \Delta^{18} \mathrm{O}_{\text {opx-ol }}$, and $\Delta^{18} \mathrm{O}_{\mathrm{pl} \text {-ol }}$ values calculated for the T5-2 trachyandesite from the MOT were $-0.09,0.41$, and 0.75 , respectively. The $\Delta^{18} \mathrm{O}_{\text {cpx-ol }}, \Delta^{18} \mathrm{O}_{\text {opx-ol }}$, and $\Delta^{18} \mathrm{O}_{\mathrm{pl}-\mathrm{ol}}$ values calculated for the T9-1 basaltic andesite from the SOT were $0.16,0.67$, and 0.66 , respectively. These data imply that the crystallization of the magma and minerals preferentially incorporated isotopically heavy $\mathrm{O}$ into the orthopyroxene and plagioclase phenocrysts, resulting in the relative enrichment of lighter $\mathrm{O}$ isotope in the olivine phenocrysts.

The $\mathrm{Mg}$ isotope compositions of the OT volcanic lavas and their minerals varied from $-0.31 \%$ o to $-0.09 \%$ o (Table S9 and Figure $5 \mathrm{e}$ ). No correlations existed between $\mathrm{Mg}$ isotopes and $\mathrm{SiO}_{2}$ concentrations for whole-rock samples (Figure S3c). The $\delta^{26} \mathrm{Mg}$ values of the $\mathrm{R} 2$ basalt from the MOT ranged from -0.31 to $-0.20 \%$, and all the values fell within the MORB range $\left(-0.26 \% \pm 0.07 \%\right.$ ) [107] (Figure 5e,f and Table S9). The whole-rock $\delta^{26} \mathrm{Mg}$ values $(-0.25 \%$ o to $-0.11 \%$ ) of the MOT andesite (T2) and trachyandesite (T5-2) were slightly higher than those of MORBs. All the $\delta^{26} \mathrm{Mg}$ values $(-0.16 \%$ o to $-0.09 \%$ o of the T9-1 basaltic andesite from the SOT were higher than those of MORBs (Figure 5e,f). The $\delta^{26} \mathrm{Mg}$ values of the clinopyroxene, orthopyroxene, and glass in the T9-1 basaltic andesite from the SOT were higher than the $\delta^{26} \mathrm{Mg}$ values of those from the MOT volcanic lavas (Table S9 and Figure 5e). Furthermore, the $\Delta^{26} \mathrm{Mg}_{\text {cpx-ol }}$ value calculated for the R2 basalt from the MOT was -0.01 . The $\Delta^{26} \mathrm{Mg}_{\text {cpx-ol }}$ and $\Delta^{26} \mathrm{Mg}_{\text {opx-ol }}$ values calculated for the T5-2 trachyandesite from the MOT were -0.01 and -0.02 , respectively. The $\Delta^{26} \mathrm{Mg}_{\text {cpx-ol }}$ and $\Delta^{26} \mathrm{Mg}_{\text {opx-ol }}$ values calculated for the T9-1 basaltic andesite from the SOT were 0.02 and 0.01 , respectively.

However, only the $\delta^{7} \mathrm{Li}(+3.33 \%$ o to $+4.09 \%$ o $), \delta^{18} \mathrm{O}(+5.41 \%$ o to $+5.78 \%$ o $)$, and $\delta^{26} \mathrm{Mg}$ $(-0.28 \%$ o to $-0.20 \%$ o values of the glass or whole rock from the mafic R2 basalt might be considered indicative of magma source compositions.

\section{Discussion}

\subsection{Genesis and Evolution of Magmas}

The crystallization temperatures and pressure ranges (Tables S2-S6) of the corresponding ascending magmas were estimated from the pyroxene compositions of the volcanic lavas (Section 4.1) [84,85,112,113]. The crystallization temperature, pressure, and magma 
depth for forming the orthopyroxene phenocrysts in T6-2 rhyolites from the MOT were lower and shallower than those for forming the clinopyroxene phenocrysts in the R2 basalt, the orthopyroxene phenocrysts in the T2 andesite from the MOT, and the orthopyroxene phenocrysts in the T9-1 basaltic andesite from the SOT (Tables S2-S6, Figure 6). The average depths of ascending magmas for forming the clinopyroxene phenocrysts in the R2 basalt, orthopyroxene phenocrysts in the T2 andesite, orthopyroxene phenocrysts in T6-1 rhyolites from the MOT, and orthopyroxene phenocrysts in the T9-1 basaltic andesite from the SOT were estimated to be $11.3 \mathrm{~km}(n=11), 10.9 \mathrm{~km}(n=14), 12.7 \mathrm{~km}(n=28)$, and $12.6 \mathrm{~km}$ $(n=13)$, respectively. These results suggest that the ascending magmas for forming the R2 basalt, T2 andesite, and T6-1 rhyolites in the MOT and the T9-1 basaltic andesite in the SOT originated from near the crust-mantle transition zone (13-14 km) [62].

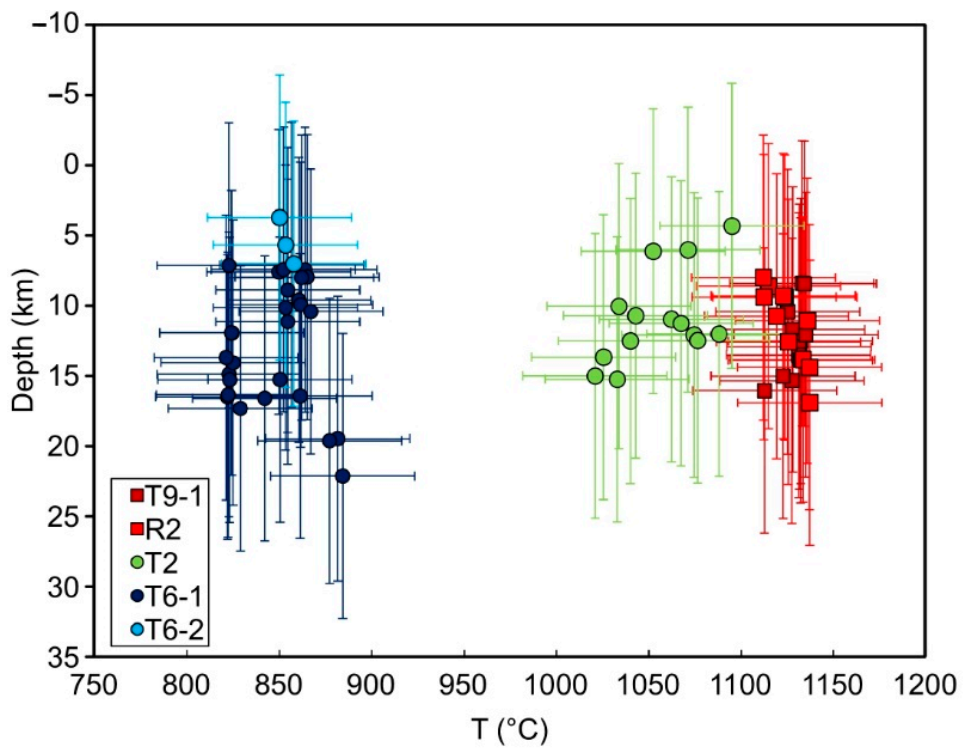

Figure 6. Crystallization temperatures and magma source depths for the MOT and SOT volcanic lavas.

The LILE, $\mathrm{Pb}$, and $\mathrm{Sr}$ enrichments and the $\mathrm{Nb}$, Ta, and $\mathrm{Ti}$ depletions in the MOT and SOT lavas (Figure 4) produced trace element distribution patterns similar to those of the continental crust [114]. If considerable crustal contamination or magma mixing occurred, the ${ }^{87} \mathrm{Sr} /{ }^{86} \mathrm{Sr}$ and ${ }^{143} \mathrm{Nd} /{ }^{144} \mathrm{Nd}$ of the volcanic lavas would then increase and decrease, respectively, with increasing $\mathrm{SiO}_{2}$ [12,89]. However, except for the T6-1 and T6-2 rhyolites, the ${ }^{87} \mathrm{Sr} /{ }^{86} \mathrm{Sr}$ and ${ }^{143} \mathrm{Nd} /{ }^{144} \mathrm{Nd}$ of the MOT and SOT volcanic lavas remained nearly constant with increasing $\mathrm{SiO}_{2}$ content (Figure 7), which is unlikely to suggest mixing or assimilation between variably evolved OT magmas, indicating that crustal contamination had a minimal effect on the evolution of MOT and SOT magmas. However, the ${ }^{87} \mathrm{Sr} /{ }^{86} \mathrm{Sr}$ ratios of MOT volcanic lavas could be strongly affected by the involvement of AOC or sediments, resulting in elevated ${ }^{87} \mathrm{Sr} /{ }^{86} \mathrm{Sr}$ ratios in the $\mathrm{R} 2$ and T2 volcanic lavas. Furthermore, as observed in the Harker diagrams (Figure S2), the significant negative correlations among $\mathrm{SiO}_{2}$ and $\mathrm{Al}_{2} \mathrm{O}_{3}, \mathrm{CaO}, \mathrm{FeO}_{\mathrm{t}}$, and $\mathrm{MgO}$ highlight the fractional crystallization of olivine, clinopyroxene, and plagioclase [115]. $\mathrm{P}_{2} \mathrm{O}_{5}$ and $\mathrm{TiO}_{2}$ initially increased and then decreased with increasing $\mathrm{SiO}_{2}$ content, suggesting that apatite fractionally crystallized after the $\mathrm{SiO}_{2}$ content reached $>60 \%$. Magnetite fractionally crystallized when the $\mathrm{SiO}_{2}$ content was $>55 \%$ (Figure S2) [115,116].

The sample locations, trace element patterns, and $\mathrm{Sr}-\mathrm{Nd}$ isotopic compositions of the T5-2 trachyandesite $\left(27^{\circ} 32.86^{\prime} \mathrm{N}, 126^{\circ} 59.36^{\prime} \mathrm{E}, 1283 \mathrm{~m}\right)$ and $\mathrm{T} 2$ andesite in the MOT $\left(27^{\circ} 32.76^{\prime} \mathrm{N}, 126^{\circ} 58.52^{\prime} \mathrm{E}, 1240 \mathrm{~m} ;{ }^{87} \mathrm{Sr} /{ }^{86} \mathrm{Sr}=0.704522,{ }^{143} \mathrm{Nd} /{ }^{144} \mathrm{Nd}=0.512865\right)$ [74] were similar to those previously reported for MOT andesite $\left(287-2: 27^{\circ} 29.50^{\prime} \mathrm{N}, 126^{\circ} 50.00^{\prime} \mathrm{E}\right.$, $1380 \mathrm{~m} ;{ }^{87} \mathrm{Sr} /{ }^{86} \mathrm{Sr}=0.704252,{ }^{143} \mathrm{Nd} /{ }^{144} \mathrm{Nd}=0.512806$ ) [73] (Figure 4c), indicating that samples T5-2, T2, and 287-2 may be derived from a similar magma source [117]. Furthermore, 
Li, et al. [74] and Shinjo and Kato [73] suggested that the 287-2 and T2 samples were formed by fractional crystallization of basaltic magmas, implying that the T5-2 sample was also produced in this way. Similarly, the sampling location (Table S1), trace element distribution pattern, and Sr-Nd isotope compositions of the R2 basalt from the MOT $\left(27^{\circ} 32.47^{\prime} \mathrm{N}\right.$, $\left.126^{\circ} 58.62^{\prime} \mathrm{E}, 1309.7 \mathrm{~m} ;{ }^{87} \mathrm{Sr} /{ }^{86} \mathrm{Sr}=0.704188,{ }^{143} \mathrm{Nd} /{ }^{144} \mathrm{Nd}=0.512763\right)$ [74] were similar to those of Type 1 basalt (A6: $27^{\circ} 31.33^{\prime} \mathrm{N}, 126^{\circ} 56.60^{\prime} \mathrm{E}, 967 \mathrm{~m} ;{ }^{87} \mathrm{Sr} /{ }^{86} \mathrm{Sr}=0.704044$, ${ }^{143} \mathrm{Nd} /{ }^{144} \mathrm{Nd}=0.512827$ ) (Figure $4 \mathrm{~b}$ ) previously reported by [50], indicating that the $\mathrm{R} 2$ sample and Type 1 sample A6 from [50] were both produced by the crystallization of a similar magma source and did not suffer notable crustal contamination or undergo any assimilation and fractional crystallization (AFC) processes [50].

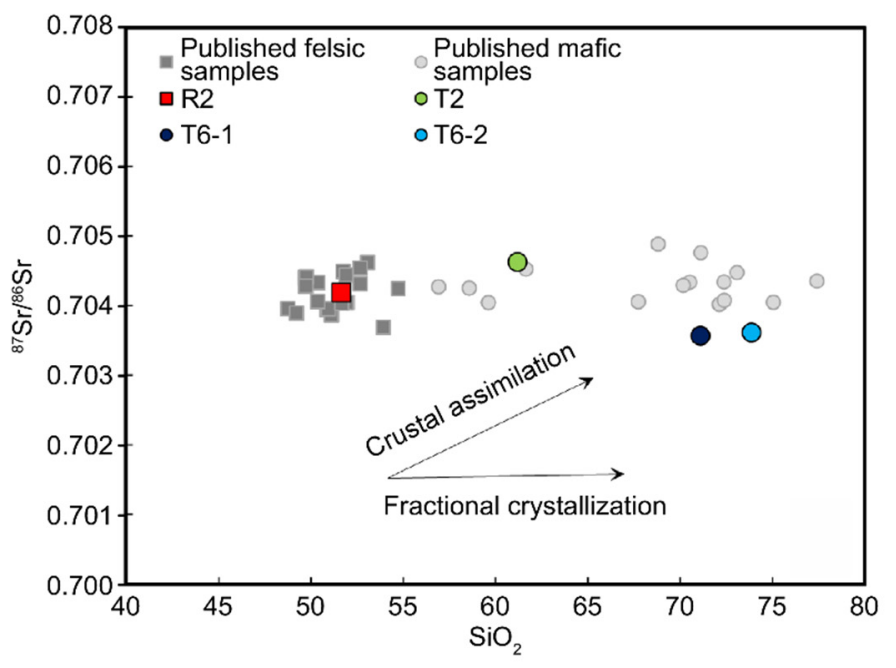

(a)

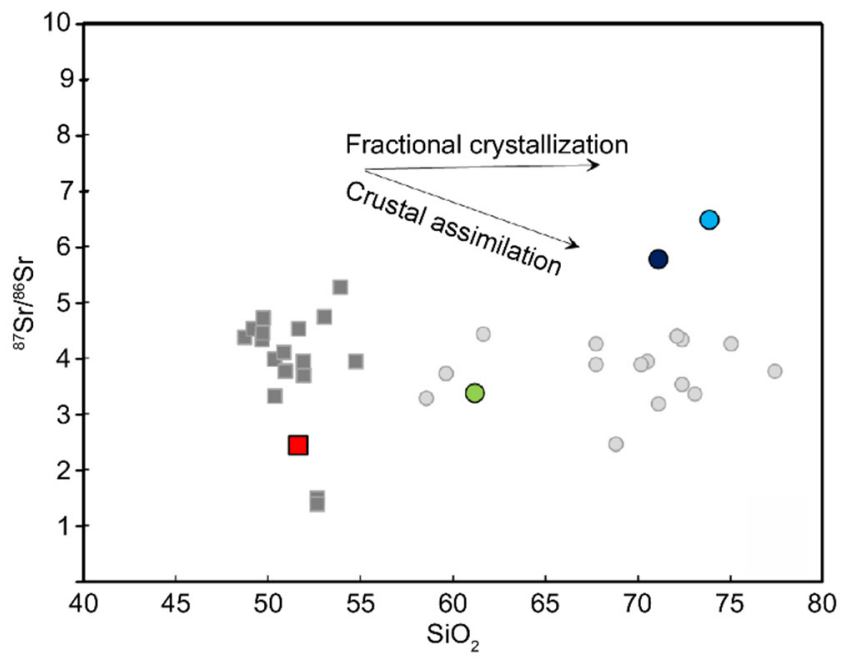

(b)

Figure 7. (a) $\mathrm{SiO}_{2}$ vs. ${ }^{87} \mathrm{Sr} /{ }^{86} \mathrm{Sr}$ and (b) $\mathrm{SiO}_{2}$ vs. ${ }^{143} \mathrm{Nd} /{ }^{144} \mathrm{Nd}$ plots showing that crustal assimilation slightly influenced the magmatic evolution of the MOT and SOT volcanic lavas. Data for published mafic samples are from $[1,36,50,74]$. Data for published felsic samples are from $[1,73,74]$. Data for samples T6-1, T2, and T6-2 are from this study.

However, the T9-1 basaltic andesite from the SOT had lower trace element and REE concentrations than the R2 basalt from the MOT (Table S8, Figure 4a,b), implying that the T9-1 basaltic andesite and the R2 basalt originated from different magmatic sources and evolved through different processes [50]. Furthermore, the trace element distribution pattern of the T9-1 basaltic andesite from the SOT differed from those of other SOT samples previously reported by [50], suggesting that the source of the SOT magma was heterogeneous and that fractional crystallization of a primitive magma was insufficient to form the different compositions of the SOT magmas [50].

In addition, the T6-1 and T6-2 samples were obtained from the western slope of the trough (Figure 1), and they exhibited the lowest and highest ${ }^{87} \mathrm{Sr} /{ }^{86} \mathrm{Sr}$ and ${ }^{143} \mathrm{Nd} /{ }^{144} \mathrm{Nd}$, respectively, among all the OT samples (Figure 7). These pumices all had lower crystallization temperatures and magma depths than the T2 samples obtained from the Iheya Ridge (Figure 6). Zhang, et al. [118] analyzed the geochemistry of the T6-1 and T6-2 pumices and concluded that they did not originate from MOT basaltic rocks through either partial melting or fractional crystallization processes; rather, they were generated from a potassium-rich magma source in the OT. The trace element and REE patterns of the T6-1 and T6-2 rhyolites from the MOT resemble those of Type 2 rhyolites previously reported by [73] (Table S8 and Figure 4e), which can be explained by AFC processes in the MOT basaltic magma [73]. Therefore, the T6-1 and T6-2 rhyolites from the MOT originated from different magma sources and underwent magmatic evolution histories different from those of other MOT samples. 


\subsection{Influence of Subduction Components Inferred from Trace Elements}

The MOT basalts and SOT basaltic andesite were notably enriched in LILEs and $\mathrm{Pb}$ and were depleted in HFSEs (Figure 4 and Table S8), indicating that the magma from which these lavas formed had been affected by subduction component input [9]. On the $\mathrm{Ba} / \mathrm{La}$ vs. Th/ $\mathrm{Rb}$ and $\mathrm{Ce} / \mathrm{Pb}$ vs. Ba/La diagrams (Figure 8 ), all the MOT and SOT whole-rock samples plot are within the subducted sediment zone, indicating that all these volcanic lavas have been affected by subducted sediments. The $\mathrm{Ba} / \mathrm{La}$ vs. Th/ $\mathrm{Yb}$ and $\mathrm{Ba} / \mathrm{Th}$ vs. $\mathrm{Th} / \mathrm{Nb}$ diagrams (Figure 8) also show that the MOT and SOT trace element ratios trend toward sediment assimilation. All these diagrams suggest that the OT volcanic rocks have been affected by subducted sediment. However, whether slab-derived fluids influenced the mantle beneath the back-arc is still uncertain.
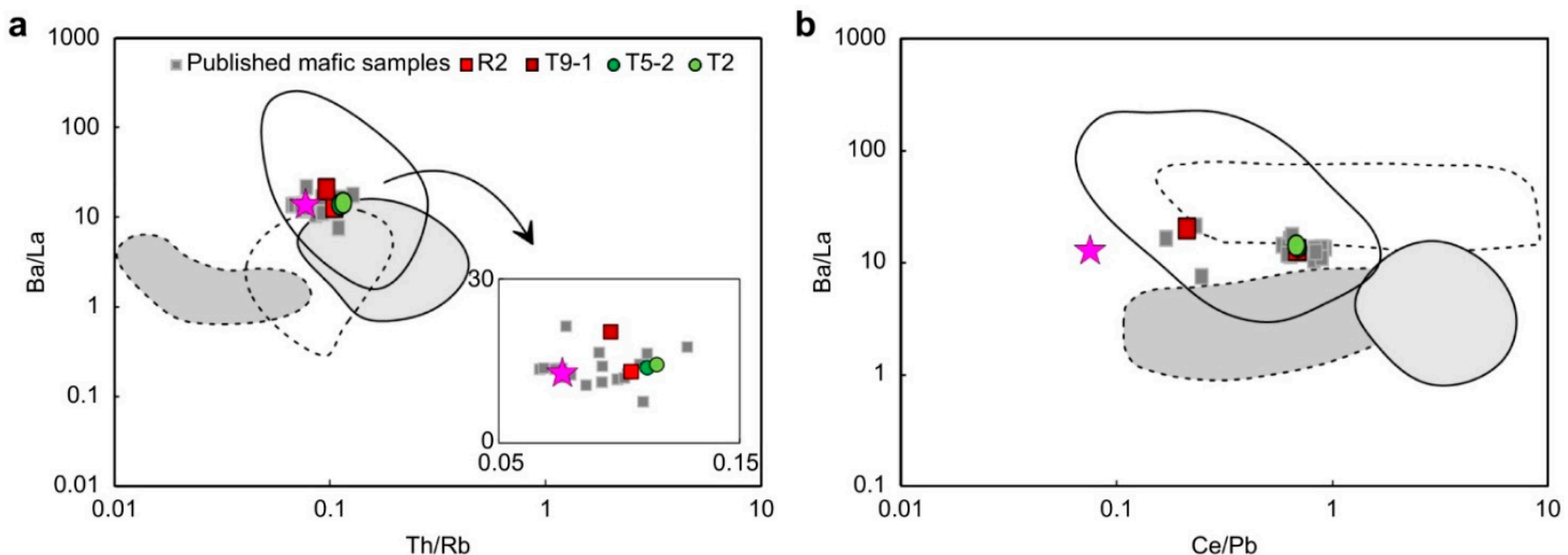

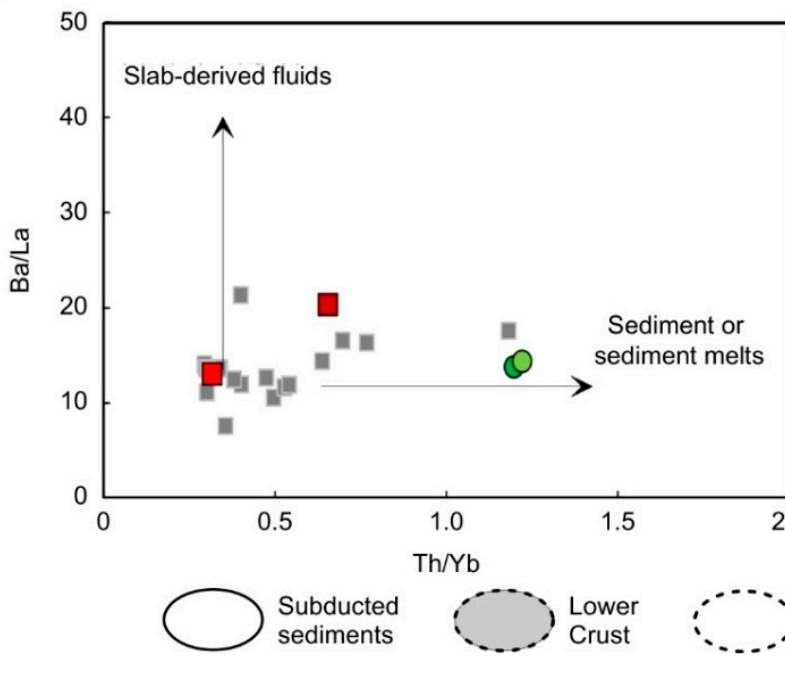

d

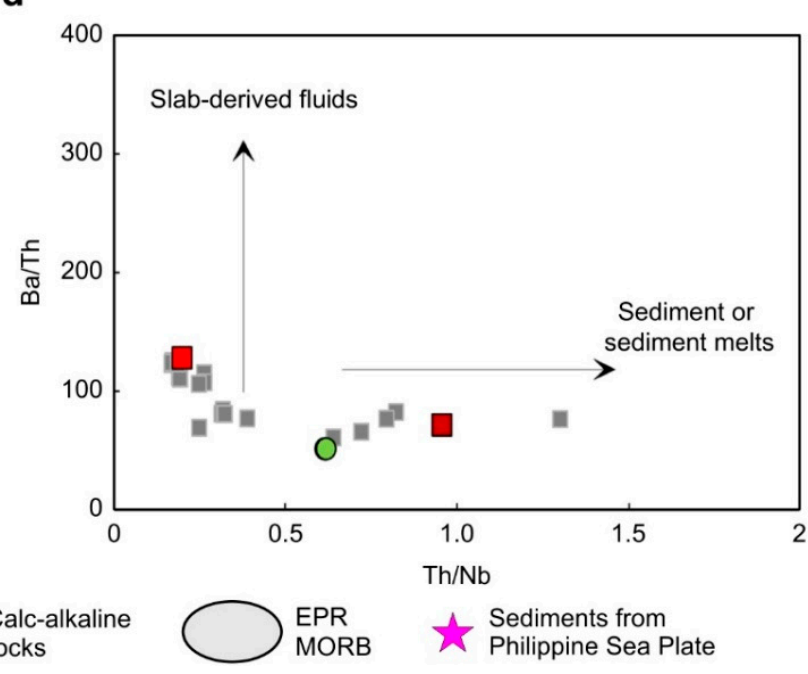

Figure 8. Trace element ratio plots: (a) Th/Rb vs. $\mathrm{Ba} / \mathrm{La}$, (b) $\mathrm{Ce} / \mathrm{Pb}$ vs. $\mathrm{Ba} / \mathrm{La}$, (c) $\mathrm{Th} / \mathrm{Yb}$ vs. $\mathrm{Ba} / \mathrm{La}$, and (d) Th/Nb vs. Ba/Th for the MOT and SOT volcanic lavas. Compositions of the EPR MORB data are from PetDB database (www.earthchem.org/petdb accessed on 10 December 2021). Subducted sediment compositions are from [10]. Canary ocean island basalt (OIB) contents are from [119]. Calc-alkaline basalt contents are from $[120,121]$, and the values for the lower crust in the North China Craton are from [122]. Data for published mafic samples are from [1,36,50,74]. Data for published felsic samples from $[1,73,74]$. Data for samples R2, T5-2, T6-1, T2, and T6-2 in the MOT and T9-1 in the SOT are from this study.

The $\mathrm{Pb}$ content of crustal sediments (19.9 ppm) [10] is two orders of magnitude greater than that of the mantle $(0.6 \mathrm{ppm})[12,90]$, and the addition of dehydration fluids from the subducting plate can increase the contents of fluid-active elements [108]. However, 
the ratios of fluid-inactive elements to active elements, such as the $\mathrm{Nd} / \mathrm{Pb}$ ratio (1.33) of the T9-1 basaltic andesite from the SOT, were notably lower than those of MOT samples (basalt $=4.65$, andesite $=3.80$, trachyandesite $=3.79$, and rhyolites $=2.15-3.16$ ), and the $\mathrm{Nd} / \mathrm{Pb}$ ratios of all MOT and SOT samples were lower than that of the primitive mantle ( 7.3) [90], suggesting that a Pb-rich component (i.e., subducted sediment) was present in the OT magma source [12].

The $\mathrm{Ba} / \mathrm{La}$ vs. Th/Yb and $\mathrm{Ba} / \mathrm{Th}$ vs. Th/Nb diagrams (Figure 8 ) show that the MOT and SOT samples trend toward sediment assimilation, which suggests that the OT volcanic lavas were affected mainly by subducted sediment-derived melts and that subduction fluids had less influence on the magma. Furthermore, the Ba/La ratio of the SOT basaltic andesite (20.32) was considerably higher than those of MOT basalt (13.05), andesite (13.79), trachyandesite (14.35), and rhyolites (11.76-14.81). The $\mathrm{Ce} / \mathrm{Pb}$ ratio of the $\mathrm{T} 9-1$ basaltic andesite (2.11) from the SOT was significantly lower than those of MOT samples (4.99-7.05). Compared to the $\mathrm{Ba} / \mathrm{La}$ ratios of MOT volcanic rocks (11.76-14.81), the Ba/La ratios (20.32) of T9-1 basaltic andesite from the SOT were closer to the $\mathrm{Ba} /$ La ratios of sediment in the Philippines Sea (25.11) [10] (Figure 8), all of which indicate that the SOT magma from which the T9-1 basaltic andesite formed was affected by subducted sediments $[8,12-14,74,115]$.

\subsection{Subduction Input of Low- $\delta^{7}$ Li Components to the OT Magmas}

The Li isotope characteristics of back-arc volcanic lavas are known to be potentially influenced by subducted slab-derived components [1,123,124], which include AOC-derived hydrous fluids, subducted sediments, and oceanic crust- and/or sediment-derived silicate melts $[125,126]$. Although the low $\delta^{7} \mathrm{Li}$ values are not consistent with subduction fluids or the asthenosphere (i.e., MORBs), they may be related to the melting of a dehydrated slab $[4,96,124,127]$. Previous research has demonstrated that low $\delta^{7} \mathrm{Li}$ values can be interpreted as dehydration signatures resulting from the hydrothermal alteration of oceanic crust $(-10.90 \%$ o to $+20.80 \%$ ) [26,94]. During high-temperature plate subduction processes, low $-\delta^{7} \mathrm{Li}$ components are released and interact with the upper mantle, thereby resulting in low $\delta^{7} \mathrm{Li}$ values in the range of $-6 \%$ to $+10 \%$ [35]. Other studies have shown that alteration of the upper oceanic crust at high-temperature can also result in low $\delta^{7} \mathrm{Li}$ values (e.g., $-1.7 \%$ ) $[26,128]$, and forearc serpentinites exhibit $\delta^{7} \mathrm{Li}$ values of less than $-6 \%$ [35] Additionally, eclogites, which represent dehydrated oceanic crust, have low $\delta^{7} \mathrm{Li}$ values $(-11 \%$ o to $+0.3 \%$ o $)$, and the direct melting of such siliceous eclogites could result in low $-\delta^{7} \mathrm{Li}$ melts [28]. Some sediments, especially young oceanic sediments that have not been altered by seawater, also exhibit low $\delta^{7} \mathrm{Li}$ values $(-4.31 \%$ o to $+23.33 \%$ ) [27]. Thus, fluids with relatively low $\delta^{7} \mathrm{Li}$ values may also be released from subducted sediments [3].

The $\delta^{7} \mathrm{Li}$ values of glass and whole-rock samples from the T5-2 trachyandesite, T2 andesite, R2 basalt in the MOT and the T9-1 basaltic andesite in the SOT were significantly lower than those of whole-rock data for T6-1 and T6-2 rhyolites in the MOT (Table S9). This contrast implies that the magmas from which the T5-2 trachyandesite, T2 andesite, and R2 basalt in the MOT and the T9-1 basaltic andesite in the SOT formed could have been affected by a low $-\delta^{7} \mathrm{Li}$ component that may be released from oceanic sediments or subducted AOC.

Furthermore, previous research has shown that Li isotopes are not fractionated in closed systems at temperatures greater than $350^{\circ} \mathrm{C}[33,129,130]$. Thus, Li isotopes are not expected to have fractionated during OT magma evolution [33,131,132]. However, the $\delta^{7} \mathrm{Li}$ values of clinopyroxene in the T5-2 trachyandesite $(-0.83 \%$ o ) from the MOT and T9-1 basaltic andesite $(0.49 \%$ o from the SOT and of plagioclase in the R2-1 basalt $(-0.71 \%$ o from the MOT and T9-1 basaltic andesite $(-5.05 \%$ ) from the SOT were lower than those of olivine, orthopyroxene, glass (Table S9), and MORBs (+1.50\% to $+6.85 \%$ ) $[22,33,91-93]$ (Figure $5 \mathrm{a}, \mathrm{b}$ ). This difference suggests that the Li isotope compositions of plagioclase and pyroxene may have been modified by a low $-\delta^{7} \mathrm{Li}$ fluid or melt during magma evolution and that the ${ }^{6} \mathrm{Li}$ content was enriched in clinopyroxene and plagioclase during mineral crystallization and mantle metasomatism. Overall, the negative Li isotope fractionation 
$\left(\Delta^{7} \mathrm{Li}_{\mathrm{x} \text {-ol }}<0\right)$ between silicate minerals and olivine during mineral crystallization may have been due to the low- $\delta^{7} \mathrm{Li}$ components that are released from oceanic sediments or AOC.

\subsection{Subduction of Low-and High- $\delta^{18} \mathrm{O}$ Components}

For volcanic rocks, magma differentiation from mafic to felsic compositions at high temperatures does not result in significant oxygen isotope fractionation (usually less than $0.3-0.4 \%$ ) (e.g., from $5.8 \%$ for basalts to $6.1 \%$ or rhyolites at $~ 90 \%$ differentiation) $[133,134]$. The $\delta^{18} \mathrm{O}$ values of glass $(6.31 \%$ ) and plagioclase $(5.99 \%$ ) in the T5-2 trachyandesite, glass $(6.21 \%)$ and orthopyroxene $(5.86 \%$ o $)$ in the T2 andesite, the whole-rock samples of T5-2 $(6.69 \%$ ) trachyandesite, T6-1 (5.84\%), and T6-2 (6.08\%) rhyolites from the MOT (Table S9) were all higher than those of MORBs $(+5.30$ to $+5.80 \%$ ) $[110,111]$ (Figure $5 c$ ); this feature also indicates that these volcanic lava samples were produced by high- $\delta^{18} \mathrm{O}$ magmas $[135,136]$. The high $\delta^{18} \mathrm{O}$ values of the evolved magmas may be related to crustal contamination; however, no correlations were observed between the $\mathrm{Sr}-\mathrm{Nd}$ isotopes and $\mathrm{SiO}_{2}$ concentrations in OT lavas (Figure 7), suggesting that little crustal contamination occurred [11,36,50,73,74]. Alternatively, the high- $\delta \delta^{18} \mathrm{O}$ signatures could be due to the subduction of $\delta^{18} \mathrm{O}$-rich components $[110,137]$. Marine carbonates $\left(\delta^{18} \mathrm{O}=25-32 \%\right.$ ), siliceous oozes $\left(\delta^{18} \mathrm{O}=35-42 \%\right.$ ), and pelagic clays $\left(\delta^{18} \mathrm{O}\right.$ $=15-25 \%$ ), which are major components of sediments subducting beneath the volcanic arc, all have higher $\delta^{18} \mathrm{O}$ values than MORBs [2]. Therefore, the addition of subducted sediments to the magma could explain the higher $\delta^{18} \mathrm{O}$ values of MOT volcanic rock samples.

However, $\mathrm{O}$ isotopes can be used to constrain the contribution of slab melts to island arc magmas, thereby indicating the origin of a melt [2]. The $\delta^{18} \mathrm{O}$ values of the R2-1 $(5.41-5.79 \%$ ) and R2-2 (5.38-5.78\%o) basalts from the MOT fell within the MORB range (5.3-5.8\%o), implying that the volcanic lava samples in the MOT originated from mantlederived magma (Figure 5c) [111,138]. The whole-rock and mineral $\delta^{18} \mathrm{O}$ values $(5.15-6.31 \%$ ) of the T5-2 trachyandesite varied significantly (Figure 5c) and may have been affected by different magmatic components [2] during magma ascent. Moreover, the $\delta^{18} \mathrm{O}$ values of whole-rock samples $(5.29 \%$ ) , olivine $(4.83 \%$ ) and clinopyroxene $(4.99 \%$ ) from the T91 basaltic andesite in the SOT were lower than those (5.30-5.80\%o) [110,111] of MORBs (Figure $5 \mathrm{c}$ ). This result indicates the presence of a low $-\delta^{18} \mathrm{O}$ component during magma evolution $[37,139,140]$. Furthermore, AOC had a large range of $\delta^{18} \mathrm{O}$ values $(+2 \%$ o to $+14 \%$ ) [141], and the low $\delta^{18} \mathrm{O}$ values of ocean island basalts (OIBs) and MORBs can be explained by the addition of subducted oceanic crust to the magma source region [142-145]. Therefore, the low $\delta^{18} \mathrm{O}$ values of the T9-1 basaltic andesite from the SOT are attributed to siliceous melts or fluids derived from subducted AOC $[143,145]$. Furthermore, the $\delta^{18} \mathrm{O}$ value $(5.50 \%)$ of orthopyroxene in the T9-1 basaltic andesite from the SOT was lower than that $(5.86 \%$ ) of orthopyroxene in the T2 andesite from the MOT, which was consistently related to the varying crystallization temperatures (Tables S2 and S3), suggesting that the high-temperature $\left(1095-1138{ }^{\circ} \mathrm{C}\right)$ orthopyroxenes were characterized by ${ }^{16} \mathrm{O}$ enrichment in the SOT, whereas the low-temperature $\left(1020-1095^{\circ} \mathrm{C}\right)$ orthopyroxenes were characterized by ${ }^{16} \mathrm{O}$ depletion in the MOT.

As with the Li isotopes, the $\delta^{18} \mathrm{O}$ values of plagioclase and glass were higher than those of MOT and SOT olivine, clinopyroxene, and orthopyroxene (Table S9 and Figure 5c), and all the samples exhibited positive $\mathrm{O}$ isotopic fractionations between other minerals and olivine $\left(\Delta^{18} \mathrm{O}_{\mathrm{x}-\mathrm{ol}}>0\right)$. This feature suggests that compared to olivine, plagioclase and pyroxene preferentially incorporated ${ }^{18} \mathrm{O}$ rather than ${ }^{16} \mathrm{O}$ during silicate mineral crystallization, which indicates that the $\mathrm{O}$ isotope compositions of plagioclase and pyroxene may have been modified by a high- $\delta^{18} \mathrm{O}$ fluid or melt [137].

\subsection{Contribution of High- $\delta^{26} \mathrm{Mg}$ Slab Fluids}

The $\delta^{26} \mathrm{Mg}$ values of MOT volcanic samples ( $-0.21 \%$ to $-0.28 \%$ ) fell within the range of MORBs $\left(-0.26 \% \pm 0.07 \%\right.$ ) [107] (Figure 5e). The $\delta^{26} \mathrm{Mg}$ values of the T2 andesite $(-0.20$ to $-0.12 \%$ ) were similar to those of the T5-2 trachyandesite $(-0.23 \%$ to $-0.12 \%$ o (Figure 5e), both of which were slightly higher than those of MORBs (Figure 5e). The $\delta^{26} \mathrm{Mg}$ 
values $(-0.16 \%$ to $-0.09 \%$ ) of the T9-1 basaltic andesite in the SOT, which were slightly higher than those in MOT volcanic lavas (Table S9), were also higher than those of MORBs (Figure 5e), all of which indicates that these lavas may have originated from high- $\delta^{26} \mathrm{Mg}$ magmatic components $[5,39,146]$.

Previous studies have shown that higher Mg isotopes in subduction zones may originate from seawater alteration, chemical weathering, dissolution of continental crust, partial melting of oceanic crust, and/or sediment and slab dehydration [107,108,147-151]. Dissolution of continental crust can be ruled out due to the absence of correlations between the $\mathrm{Sr}-\mathrm{Nd}$ isotopic compositions and the indices of magma differentiation (e.g., $\mathrm{SiO}_{2}$; Figure 7). Furthermore, volcanic lavas can have isotopically heavier $\delta^{26} \mathrm{Mg}$ values than MORBs if they are generated by the melting of subducted oceanic crust containing a garnet residual phase because garnet has much lower $\delta^{26} \mathrm{Mg}$ values $[41,42,108,152]$. However, because the chemical compositions of our samples were quite different from those of slab products (e.g., adakites) (Figure 4), the possibility of slab melting can also be excluded. Therefore, either subducted sediments or slab dehydration may explain the high $\delta^{26} \mathrm{Mg}$ values of volcanic lava samples analyzed in this study.

On average, forearc sediments have heavy $\mathrm{Mg}$ isotope compositions $(-0.10 \pm 0.61)$ that could provide a source for volcanic lavas with heavy $\mathrm{Mg}$ isotope compositions [108]. Moreover, the $\delta^{26} \mathrm{Mg}$ values of the Avacha volcanic lavas from the Kamchatka Peninsula range from $-0.25 \%$ o to $-0.06 \%$ o (average $=-0.18 \%$ o $\pm 0.10 \%$ o (2SD) [153], which has been interpreted as the result of the lower mantle being affected by subduction fluids released by the Pacific slab [148]. Similarly, the $\delta^{26} \mathrm{Mg}$ values of the Avacha volcanic lavas are consistent with those of whole-rock samples from MOT andesite $(-0.17 \%$ o to $-0.12 \%$ o), trachyandesite $(-0.16 \%$ to $-0.12 \%$ o , and basalt $(-0.28 \%$ o to $-0.20 \%$ o $)$ and SOT basaltic andesite $(-0.11 \%$ o to $-0.09 \%$ ) , implying that fluids released from subducted sediment or oceanic crust contributed to the OT magma source.

\subsection{Mixing of Subduction Components}

The above discussion suggests that the OT magma source was influenced by both subducted sediments and AOC $[1,47,50]$. A residual slab endmember, represented by eclogite, and an AOC endmember interacting in different proportions with a MORBproducing magma could produce lavas with different $\delta^{7} \mathrm{Li}, \delta^{18} \mathrm{O}$, and $\delta^{26} \mathrm{Mg}$ values [7,20,33]. According to the $\delta^{18} \mathrm{O}$ vs. $\delta^{7} \mathrm{Li}$ and $\delta^{26} \mathrm{Mg}$ vs. $\delta^{7} \mathrm{Li}$ diagrams (Figure 9), OT volcanic lavas with different $\delta^{7} \mathrm{Li}, \delta^{18} \mathrm{O}$, and $\delta^{26} \mathrm{Mg}$ values can be produced by interactions between MORB and different proportions of subducted sediment (i.e., low $\delta^{7} \mathrm{Li}$ and high $\delta^{18} \mathrm{O}$ and $\delta^{26} \mathrm{Mg}$ ) and AOC (i.e., high $\delta^{7} \mathrm{Li}$ and low $\delta^{18} \mathrm{O}$ ), wherein the AOC, oceanic sediments, and mantle wedge (i.e., MORB) are the endmembers contributing to the MOT and SOT magmas. The whole-rock and glass data from the R2 basalt in the MOT and the T9-1 basaltic andesite occur in the SOT plot between subducted sediments and AOC, indicating that the contributions from AOC and sediments were $80 \%$ to $92 \%$ and $20 \%$ to $8 \%$, respectively; therefore, the mixing of different subduction components can produce $\mathrm{Li}, \mathrm{O}$, and $\mathrm{Mg}$ isotope characteristics in the R2 basalt from the MOT and the T9-1 basaltic andesite from the SOT (Figure 9 and Table S9).

\subsection{Implications of Differences in Plate Subduction}

As discussed above, the SOT magma from which the T9-1 basaltic andesite formed was influenced by more slab-derived fluids, although the supporting data are limited. However, the thermal structure of a subduction zone is the key to determining the depth at which the subducted slab dehydrates [154-157], and this thermal structure is mainly determined by the depth of the subducted slab, age of the subducting plate, convergence rate, subduction zone geometry (especially the subduction angle), subduction zone shear heating rate, and nature of the mantle wedge [11,65,123,155,157]. Furthermore, dehydration usually decreases with increasing subduction depth $[47,123,158]$, and most subducted slabs dehydrate considerably at a depth of $\sim 80 \mathrm{~km}$, leaving $<1 \%$ of the water to be carried deeper 
by the subducting slab [154]. The subducting plates lose notable volumes of water at relatively shallow depth (modeled here at a depth of $80 \mathrm{~km}$ ), and the further dehydration of most slabs is only minor (e.g., Kamchatka and Calabria) (Figure S4).

a

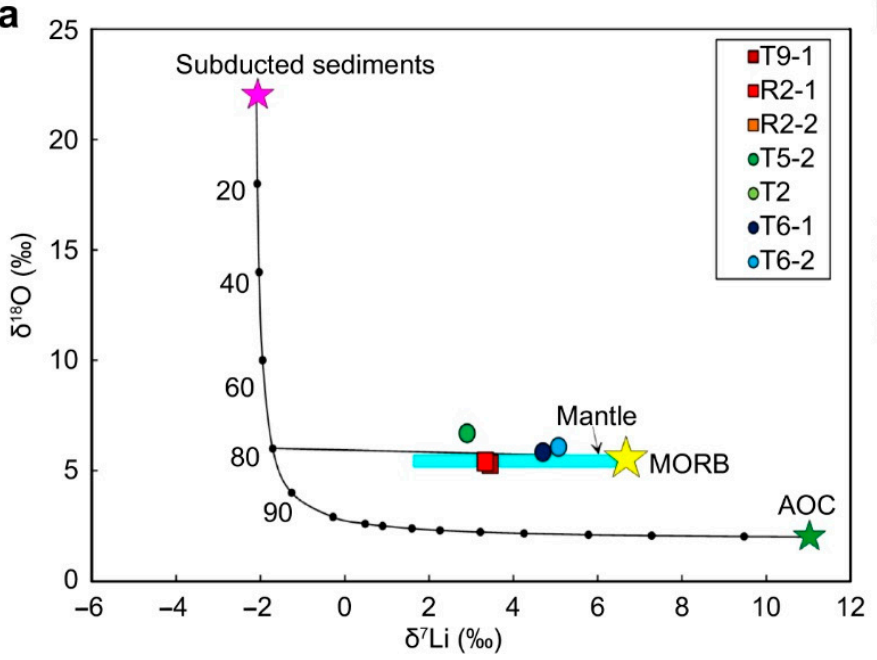

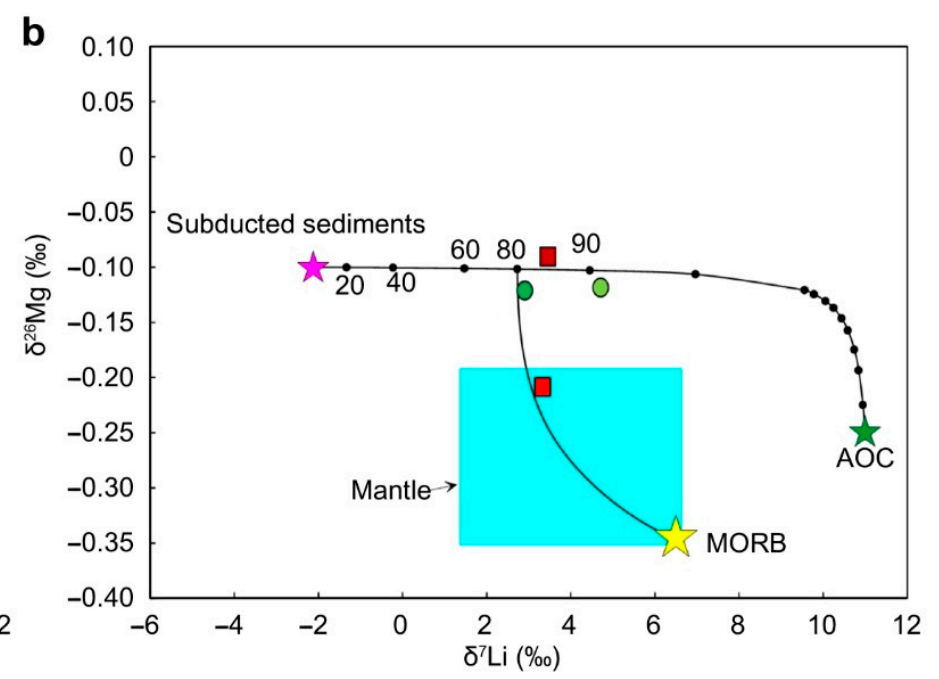

Figure 9. Plots of (a) $\delta^{18} \mathrm{O}$ vs. $\delta^{7} \mathrm{Li}$ and (b) $\delta^{26} \mathrm{Mg}$ vs. $\delta^{7} \mathrm{Li}$ for the MOT and SOT samples. Isotopic compositions $\left(\delta^{18} \mathrm{O}=2 \%\right.$, $\delta^{7} \mathrm{Li}=11 \%$, and $\delta^{26} \mathrm{Mg}=-0.25 \%$ o $)$ of AOC are from $[33,39,137]$, respectively. Isotopic compositions $\left(\delta^{18} \mathrm{O}=22 \%\right.$, $\delta^{7} \mathrm{Li}=-2.1 \%$, and $\delta^{26} \mathrm{Mg}=-0.1 \%$ of subducted sediments are from $[7,33,108]$, respectively. Isotope compositions $\left(\delta^{18} \mathrm{O}=5.5 \%\right.$, $\delta^{7} \mathrm{Li}=6.5 \%$, and $\delta^{26} \mathrm{Mg}=-0.35 \%$ ) of mid-ocean ridge basalts (MORBs) are from $[22,107,110]$, respectively.

The OT is influenced by the subduction of the PSP, and the difference between the subduction rates of the SOT and the MOT is relatively small $[11,50,56,69]$. Therefore, the difference between the subduction rates likely had only a limited impact on plate dehydration $[47,50,157]$. Furthermore, the subduction direction of the PSP is nearly perpendicular to the axis of the MOT and becomes oblique to the SOT [11,50,65]. Although the slab subduction angle beneath the SOT is higher compared to that beneath the MOT, this small difference does not significantly influence slab material transport [11,47,50]. Moreover, the difference between the crustal thicknesses of the MOT and the SOT (i.e., $\sim 16$ and $\sim 14 \mathrm{~km}$, respectively) is negligible when compared to the subduction depths of the PSP in the MOT and SOT ( 200 and $\sim 150 \mathrm{~km}$, respectively), suggesting that the slight difference between the crustal thicknesses of the MOT and the SOT is not enough to cause different degrees of slab dehydration. However, this difference may reflect the degree of crustal contamination when the magma ascends from a deep magma chamber.

The Ryukyu subduction zone has a fairly rapid subduction rate ( 82 mm/a) [159], which is in line with that of cold subduction zone structures [47], suggesting that large degrees of dehydration occurred when the slab reached depths of $\sim 80$ to $100 \mathrm{~km}$, at which point sediment fluid/melt entered the mantle wedge [157]. Moreover, the ascending magma from which the T9-1 basaltic andesite in the SOT formed corresponds to a WadatiBenioff zone depth of $\sim 150 \mathrm{~km}$, and the MOT has Wadati-Benioff zone depths of $\sim 150$ to $200 \mathrm{~km}$ (Figure 1). However, compared with the PSP subducting slab (depths: 150 to $200 \mathrm{~km}$ ) in the MOT, the PSP subducting slab in the SOT exhibits a significantly shallower subduction depth $(\sim 150 \mathrm{~km})$, which is consistent with the variation in the subduction angle, i.e., nearly perpendicular beneath the MOT and becoming progressively more oblique beneath the SOT $[11,50,65]$. This variation indicates that the subducting slab (depth of $\sim 150 \mathrm{~km}$ ) beneath the SOT was closer to the ascending magma (avg. depth $=12.6 \mathrm{~km})$ that formed the T9-1 basaltic andesite in the SOT than the subducting slab (depth of $\sim 200 \mathrm{~km}$ ) beneath the MOT. The deep ascending magmas (depth: 8.4-16.1 km and $~ 8.0-16.9 \mathrm{~km}$ ) that formed the clinopyroxene and orthopyroxene phenocrysts with high crystallization temperatures $\left(1095-1138^{\circ} \mathrm{C}\right.$ and $1111-1137^{\circ} \mathrm{C}$, respectively) in the mafic volcanic lavas 
(SOT basaltic andesite T9-1 and MOT basalt R2) were closer to the subducted slab than the shallow ascending magma (depth: $3.7-7.1 \mathrm{~km}$ ) that formed the orthopyroxene phenocrysts with low crystallization temperatures $\left(844-858^{\circ} \mathrm{C}\right.$ ) in the felsic volcanic lavas (MOT rhyolites T6-2). These data imply that the deeper the ascending magma is, the closer it is to the subducted slab, and the stronger the influence of the subducted components on the ascending magma (Figure 10).

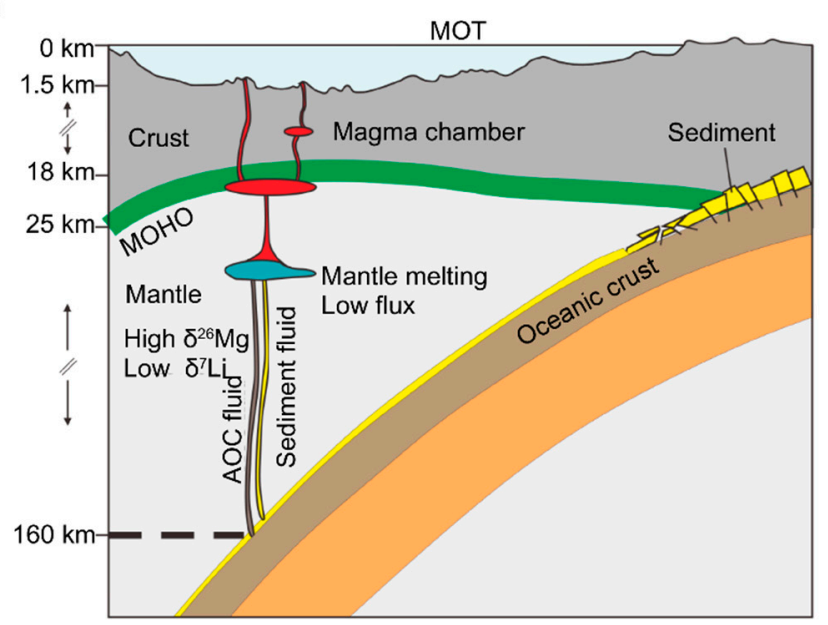

b

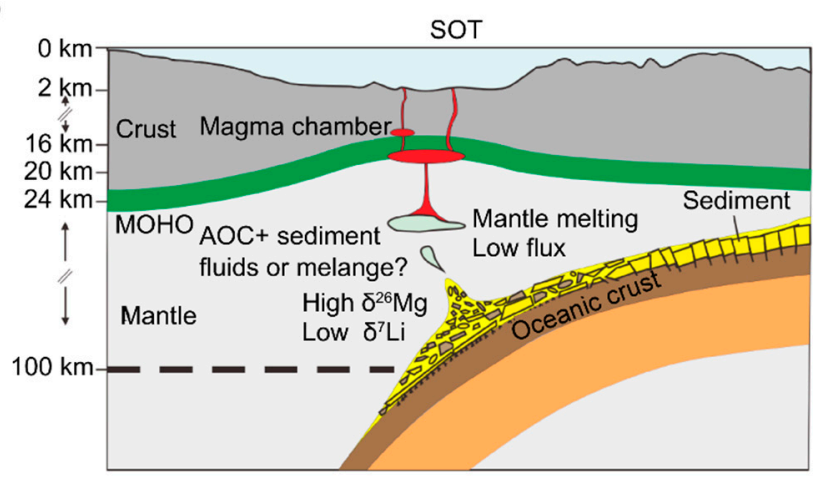

Figure 10. Schematic diagram showing the different contributions of subduction components to the (a) MOT and (b) SOT.

\section{Conclusions}

(1) The T9-1 basaltic andesite in the SOT had lower trace element contents than the MOT samples and exhibited stronger $\mathrm{Nb}$, $\mathrm{Ta}$, and $\mathrm{Ti}$ depletions and a positive $\mathrm{Pb}$ anomaly. The $\mathrm{Nd} / \mathrm{Pb}$ and $\mathrm{Ce} / \mathrm{Pb}$ ratios of the SOT basaltic andesite were significantly lower than those of the MOT volcanic lavas, while the Ba/La ratio of the SOT basaltic andesite was significantly higher, indicating that the magma from which the T9-1 basaltic andesite from the SOT formed was influenced by subduction components and experienced an injection of sediment components.

(2) The $\delta^{7} \mathrm{Li}$ values of the whole-rock samples from the T6-1 and T6-2 rhyolites in the MOT were higher than those of whole-rock and glass separates from the T5-2 trachyandesite, T2 andesite, and R2 basalt in the MOT and the T9-1 basaltic andesite in the SOT. These results imply that the magmas that formed the R2 basalt in the MOT and the T9-1 basaltic andesite in the SOT could have been affected by a low $-\delta^{7} \mathrm{Li}$ component that may have been released from oceanic sediments or subducted AOC. The $\delta^{7} \mathrm{Li}$ values of plagioclase and clinopyroxene phenocrysts were lower than those of glass and olivine in the MOT and SOT volcanic lavas, suggesting that ${ }^{6} \mathrm{Li}$ was preferentially removed from the magma and incorporated into plagioclase and clinopyroxene, resulting in relative enrichment in heavy $\mathrm{Li}$ isotopes in olivine and glass.

(3) The SOT and MOT magmas were influenced by low $-\delta^{18} \mathrm{O}$ AOC fluids or melts and high- $\delta^{18} \mathrm{O}$ sediment components, respectively. The $\delta^{18} \mathrm{O}$ values of plagioclase and glass were higher than those of olivine, clinopyroxene, and orthopyroxene phenocrysts in the MOT and SOT volcanic lavas, indicating that ${ }^{16} \mathrm{O}$ was preferentially removed from the magma and incorporated into olivine, clinopyroxene, and orthopyroxene, resulting in the relative enrichment in heavy ${ }^{18} \mathrm{O}$ isotopes in plagioclase phenocrysts and glass.

(4) The $\delta^{26} \mathrm{Mg}$ values of clinopyroxene, orthopyroxene, and glass were higher in the T9-1 basaltic andesite from the SOT than those in the MOT volcanic lavas, and the $\delta^{18} \mathrm{O}$ values of the T9-1 basaltic andesite from the SOT were lower than the $\delta^{18} \mathrm{O}$ of whole-rock volcanic samples from the MOT. These differences imply that the influence of subduction components with high $\delta^{26} \mathrm{Mg}$ and low $\delta^{18} \mathrm{O}$ values was stronger in the SOT than in the 
MOT, which may have occurred because the amount of subducted sediment and AOC dehydration fluids injected into the magma in the SOT was larger than that in the MOT.

(5) The $\delta^{18} \mathrm{O}$ and $\delta^{26} \mathrm{Mg}$ values of pyroxenes in the SOT were lower and higher than those in the MOT, respectively, which is consistent with the variations from the SOT to the MOT in the crystallization temperatures, pressures, and depths of the ascending magmas from which volcanic lavas formed. These results suggest that high-temperature pyroxenes originating from a deep magma (avg. depth $=12.6 \mathrm{~km}, n=13$ ), which was located near the crust-mantle transition zone (13-14 km), are characterized by ${ }^{16} \mathrm{O}$ and ${ }^{26} \mathrm{Mg}$ enrichments in the SOT. Low-temperature pyroxenes originating from a shallow magma (avg. depth $=10.9 \mathrm{~km}, n=14)$ are characterized by ${ }^{16} \mathrm{O}$ and ${ }^{26} \mathrm{Mg}$ depletions in the MOT. However, the distance between the subducting slab and the overlying magma may have played a significant part in controlling the differences between the MOT and SOT in the amounts of subduction components injected into the magma. The deeper the magma is, the closer it is to the subducted slab, and the stronger the effects of the subducted inputs on the magma.

Supplementary Materials: The following are available online at https:/ /www.mdpi.com/article/10.3390/ jmse10010040/s1, Figures S1-S4, Tables S1-S9, and Text S1. These materials include (1) additional analytical methods, (2) major elements, trace elements, and isotopes data obtained in this study, and (3) additional plots for major elements and isotopes.

Author Contributions: Conceptualization, Z.Z.; methodology, X.L.; investigation, Z.Z., X.L., Y.Z. and H.Q.; resources, Z.Z.; data curation, H.Q.; writing—original draft preparation, Z.Z. and X.L.; writing-review and editing, Y.Z.; supervision, Z.Z.; project administration, Z.Z.; funding acquisition, Z.Z. All authors have read and agreed to the published version of the manuscript.

Funding: This work was supported by the NSFC Major Research Plan on West-Pacific Earth System Multispheric Interactions (project number: 91958213), the National Program on Global Change and Air-Sea Interaction (Grant No. GASI-GEOGE-02), the Taishan Scholar Foundation of Shandong Province (Grant No. ts201511061), and the National Basic Research Program of China (Grant No. 2013CB429700).

Institutional Review Board Statement: Not applicable.

Data Availability Statement: All the data that support the findings in this study are given in the Supporting Information or by contacting the corresponding author.

Acknowledgments: We would like to thank the crews of the R/V KEXUE during the HOBAB 2 and 4 cruises for their help with the sample collection. We thank Professor Yilin Xiao and Professor Fang Huang for performing the lithium, oxygen, and magnesium isotope analyses. We are most grateful for the detailed and constructive comments and suggestions provided by Professor David Selby of the Department of Earth Sciences, University of Durham, which greatly improved an earlier version of the manuscript.

Conflicts of Interest: The authors declare no conflict of interest.

\section{References}

1. Guo, K.; Zhai, S.; Yu, Z.; Wang, S.; Zhang, X.; Wang, X. Geochemical and Sr-Nd-Pb-Li isotopic characteristics of volcanic rocks from the Okinawa Trough: Implications for the influence of subduction components and the contamination of crustal materials. J. Mar. Syst. 2018, 180, 140-151. [CrossRef]

2. Bindeman, I.N.; Eiler, J.M.; Yogodzinski, G.M.; Tatsumi, Y.; Stern, C.R.; Grove, T.L.; Portnyagin, M.; Hoernle, K.; Danyushevsky, L.V. Oxygen isotope evidence for slab melting in modern and ancient subduction zones. Earth Planet. Sci. Lett. 2005, 235, 480-496. [CrossRef]

3. Chan, L.H.; Kastner, M. Lithium isotopic compositions of pore fluids and sediments in the Costa Rica subduction zone: Implications for fluid processes and sediment contribution to the arc volcanoes. Earth Planet. Sci. Lett. 2000, 183, 275-290. [CrossRef]

4. Chan, L.H.; Leeman, W.P.; You, C.F. Lithium isotopic composition of Central American volcanic arc lavas: Implications for modification of subarc mantle by slab-derived fluids: Correction. Chem. Geol. 2002, 182, 293-300. [CrossRef]

5. Chen, Y.X.; Schertl, H.P.; Zheng, Y.F.; Huang, F.; Zhou, K.; Gong, Y.Z. Mg-O isotopes trace the origin of Mg-rich fluids in the deeply subducted continental crust of Western Alps. Earth Planet. Sci. Lett. 2016, 456, 157-167. [CrossRef] 
6. Huang, P.; Li, A.; Jiang, H. Geochemical features and their geological implications of volcanic rocks from the northern and middle Okinawa Trough. Acta Petrol. Sin. 2006, 22, 1703-1712.

7. Ito, E.; Stern, R.J. Oxygen- and strontium-isotopic investigations of subduction zone volcanism: The case of the Volcano Arc and the Marianas Island Arc. Earth Planet. Sci. Lett. 1986, 76, 312-320. [CrossRef]

8. Niu, Y.; Wilson, M.; Humphreys, E.R.; O'Hara, M.J. A trace element perspective on the source of ocean island basalts (OIB) and fate of subducted ocean crust (SOC) and mantle lithosphere (SML). Episodes 2012, 35, 310-327. [CrossRef]

9. Pearce, J.A.; Peate, D.W. Tectonic implications of the composition of volcanic ARC magmas. Annu. Rev. Earth Planet. Sci. 1995, 23, 251-285. [CrossRef]

10. Plank, T.; Langmuir, C.H. The chemical composition of subducting sediment and its consequences for the crust and mantle. Chem. Geol. 1998, 145, 325-394. [CrossRef]

11. Shinjo, R. Geochemistry of high Mg andesites and the tectonic evolution of the Okinawa Trough-Ryukyu arc system. Chem. Geol. 1999, 157, 69-88. [CrossRef]

12. Yang, Y.Z.; Wang, Y.; Ye, R.S.; Li, S.Q.; He, J.F.; Siebel, W.; Chen, F. Petrology and geochemistry of Early Cretaceous A-type granitoids and late Mesozoic mafic dikes and their relationship to adakitic intrusions in the lower Yangtze River belt, Southeast China. Int. Geol. Rev. 2017, 59, 62-79. [CrossRef]

13. Taylor, B.; Martinez, F. Back-arc basin basalt systematics. Earth Planet. Sci. Lett. 2003, 210, 481-497. [CrossRef]

14. White, W.M.; Duncan, R.A. Geochemistry and geochronology of the Society Islands: New evidence for deep mantle recycling. In Earth Processes: Reading the Isotopic Code; Basu, A., Hart, S., Eds.; American Geophysical Union: Washington, DC, USA, 1996; pp. 183-206.

15. Duan, X.; Sun, H.; Yang, W.; Su, B.; Xiao, Y.; Hou, Z.; Shi, H. Melt-peridotite interaction in the shallow lithospheric mantle of the North China Craton: Evidence from melt inclusions in the quartz-bearing orthopyroxene-rich websterite from Hannuoba. Int. Geol. Rev. 2014, 56, 448-472. [CrossRef]

16. Class, C.; Miller, D.M.; Goldstein, S.L.; Langmuir, C.H. Distinguishing melt and fluid subduction components in Umnak Volcanics, Aleutian Arc. Geochem. Geophys Geosyst 2000, 1, 1004. [CrossRef]

17. Elliott, T.; Plank, T.; Zindler, A.; White, W.; Bourdon, B. Element transport from slab to volcanic front at the Mariana arc. J. Geophys. Res. Solid Earth 1997, 102, 14991-15019. [CrossRef]

18. George, R.; Turner, S.; Hawkesworth, C.; Morris, J.; Nye, C.; Ryan, J.; Zheng, S.H. Melting processes and fluid and sediment transport rates along the Alaska-Aleutian arc from an integrated U-Th-Ra-Be isotope study. J. Geophys. Res. Solid Earth 2003, 108, 2252. [CrossRef]

19. Plank, T. Constraints from thorium/lanthanum on sediment recycling at subduction zones and the evolution of the continents. J. Pet. 2005, 46, 921-944. [CrossRef]

20. Singer, B.S.; Jicha, B.R.; Leeman, W.P.; Rogers, N.W.; Thirlwall, M.F.; Ryan, J.; Nicolaysen, K.E. Along-strike trace element and isotopic variation in Aleutian Island arc basalt: Subduction melts sediments and dehydrates serpentine. J. Geophys. Res. 2007, 112, B06206. [CrossRef]

21. Brenan, J.M.; Ryerson, F.J.; Shaw, H.F. The role of aqueous fluids in the slab-to-mantle transfer of boron, beryllium, and lithium during subduction: Experiments and models. Geochim. Cosmochim. Acta 1998, 62, 3337-3347. [CrossRef]

22. Chan, L.; Edmond, J.; Thompson, G.; Gillis, K. Lithium isotopic composition of submarine basalts: Implications for the lithium cycle in the oceans. Earth Planet. Sci. Lett. 1992, 108, 151-160. [CrossRef]

23. Teng, F.Z.; Rudnick, R.L.; McDonough, W.F.; Gao, S.; Tomascak, P.B.; Liu, Y. Lithium isotopic composition and concentration of the deep continental crust. Chem. Geol. 2008, 255, 47-59. [CrossRef]

24. Wunder, B.; Meixner, A.; Romer, R.L.; Heinrich, W. Temperature-dependent isotopic fractionation of lithium between clinopyroxene and high-pressure hydrous fluids. Contrib Miner. Pet. 2006, 151, 112-120. [CrossRef]

25. Bouman, C.; Elliott, T.; Vroon, P.Z. Lithium inputs to subduction zones. Chem. Geol. 2004, 212, 59-79. [CrossRef]

26. Chan, L.H.; Alt, J.C.; Teagle, D.A.H. Lithium and lithium isotope profiles through the upper oceanic crust: A study of seawaterbasalt exchange at ODP Sites 504B and 896A. Earth Planet. Sci. Lett. 2002, 201, 187-201. [CrossRef]

27. Chan, L.H.; Leeman, W.P.; Plank, T. Lithium isotopic composition of marine sediments. Geochem. Geophys Geosyst 2006, 7, Q06005. [CrossRef]

28. Zack, T.; Tomascak, P.B.; Rudnick, R.L.; Dalpé, C.; McDonough, W.F. Extremely light Li in orogenic eclogites: The role of isotope fractionation during dehydration in subducted oceanic crust. Earth Planet. Sci. Lett. 2003, 208, 279-290. [CrossRef]

29. Marschall, H.R.; von Strandmann, P.A.E.P.; Seitz, H.M.; Elliott, T.; Niu, Y. The lithium isotopic composition of orogenic eclogites and deep subducted slabs. Earth Planet. Sci. Lett. 2007, 262, 563-580. [CrossRef]

30. Xiao, Y.; Hoefs, J.; Hou, Z.; Simon, K.; Zhang, Z. Fluid/rock interaction and mass transfer in continental subduction zones: Constraints from trace elements and isotopes $(\mathrm{Li}, \mathrm{B}, \mathrm{O}, \mathrm{Sr}, \mathrm{Nd}, \mathrm{Pb})$ in UHP rocks from the Chinese Continental Scientific Drilling Program, Sulu, East China. Contrib. Miner. Pet. 2011, 162, 797-819. [CrossRef]

31. Xiao, Y.; Sun, H.; Gu, H.; Huang, J.; Li, W.; Liu, L. Fluid/melt in continental deep subduction zones: Compositions and related geochemical fractionations. Sci. China Earth Sci. 2015, 58, 1457-1476. [CrossRef]

32. Ishikawa, T.; Nakamura, E. Origin of the slab component in arc lavas from across-arc variation of B and Pb isotopes. Nature 1994, 370, 205-208. [CrossRef] 
33. Moriguti, T.; Nakamura, E. Across-arc variation of Li isotopes in lavas and implications for crust/mantle recycling at subduction zones. Earth Planet. Sci. Lett. 1998, 163, 167-174. [CrossRef]

34. Nakamura, E.; Campbell, I.H.; Sun, S.S. The influence of subduction processes on the geochemistry of Japanese alkaline basalts. Nature 1985, 316, 55-58. [CrossRef]

35. Benton, L.D.; Ryan, J.G.; Savov, I.P. Lithium abundance and isotope systematics of forearc serpentinites, Conical Seamount, Mariana forearc: Insights into the mechanics of slab-mantle exchange during subduction. Geochem. Geophys. Geosyst. 2004, 5, Q08J12. [CrossRef]

36. Honma, H.; Kusakabe, M.; Kagami, H.; Iizumi, S.; Sakai, H.; Kodama, Y.; Kimura, M. Major and trace element chemistry and $\mathrm{D} / \mathrm{H},{ }^{18} \mathrm{O} /{ }^{16} \mathrm{O},{ }^{87} \mathrm{Sr} /{ }^{86} \mathrm{Sr}$ and ${ }^{143} \mathrm{Nd} /{ }^{144} \mathrm{Nd}$ ratios of rocks from the spreading center of the Okinawa Trough, a marginal back-arc basin. Geochem. J. 1991, 25, 121-136. [CrossRef]

37. Macpherson, C.G.; Hilton, D.R.; Mattey, D.P.; Sinton, J.M. Evidence for an ${ }^{18} \mathrm{O}$-depleted mantle plume from contrasting ${ }^{18} \mathrm{O} /{ }^{16} \mathrm{O}$ ratios of back-arc lavas from the Manus Basin and Mariana Trough. Earth Planet. Sci. Lett. 2000, 176, 171-183. [CrossRef]

38. Macpherson, C.G.; Mattey, D.P. Oxygen isotope variations in Lau Basin lavas. Chem. Geol. 1998, 144, 177-194. [CrossRef]

39. Huang, J.; Ke, S.; Gao, Y.; Xiao, Y.; Li, S. Magnesium isotopic compositions of altered oceanic basalts and gabbros from IODP site 1256 at the East Pacific Rise. Lithos 2015, 231, 53-61. [CrossRef]

40. Li, S.G.; Yang, W.; Ke, S.; Meng, X.; Tian, H.; Xu, L.; He, Y.; Huang, J.; Wang, X.C.; Xia, Q.; et al. Deep carbon cycles constrained by a large-scale mantle Mg isotope anomaly in eastern China. Natl. Sci. Rev. 2017, 4, 111-120. [CrossRef]

41. Wang, S.J.; Teng, F.Z.; Li, S.G.; Hong, J.A. Magnesium isotopic systematics of mafic rocks during continental subduction. Geochim Cosmochim Acta 2014, 143, 34-48. [CrossRef]

42. Wang, S.J.; Teng, F.Z.; Williams, H.M.; Li, S.G. Magnesium isotopic variations in cratonic eclogites: Origins and implications Earth Planet. Sci. Lett. 2012, 359-360, 219-226. [CrossRef]

43. Xiao, Y.; Teng, F.Z.; Zhang, H.F.; Yang, W. Large magnesium isotope fractionation in peridotite xenoliths from eastern North China craton: Product of melt-rock interaction. Geochim Cosmochim Acta 2013, 115, 241-261. [CrossRef]

44. Yang, W.; Teng, F.Z.; Zhang, H.F.; Li, S.G. Magnesium isotopic systematics of continental basalts from the North China craton: Implications for tracing subducted carbonate in the mantle. Chem. Geol. 2012, 328, 185-194. [CrossRef]

45. Shimoda, G.; Tatsumi, Y.; Nohda, S.; Ishizaka, K.; Jahn, B.M. Setouchi high-Mg andesites revisited: Geochemical evidence for melting of subducting sediments. Earth Planet. Sci. Lett. 1998, 160, 479-492. [CrossRef]

46. Shu, Y.; Nielsen, S.G.; Zeng, Z.; Shinjo, R.; Blusztajn, J.; Wang, X.; Chen, S. Tracing subducted sediment inputs to the Ryukyu arc-Okinawa Trough system: Evidence from thallium isotopes. Geochim Cosmochim Acta 2017, 217, 462-491. [CrossRef]

47. Guo, K.; Zeng, Z.G.; Chen, S.; Zhang, Y.X.; Qi, H.Y.; Ma, Y. The influence of a subduction component on magmatism in the Okinawa Trough: Evidence from thorium and related trace element ratios. J. Asian Earth Sci. 2017, 145, 205-216. [CrossRef]

48. Li, Z.G.; Chu, F.Y.; Dong, Y.H.; Liu, J.Q.; Chen, L. Geochemical constraints on the contribution of Louisville seamount materials to magmagenesis in the Lau back-arc basin, SW Pacific. Int. Geol. Rev. 2015, 57, 978-997. [CrossRef]

49. Pi, J.L.; You, C.F.; Wang, K.L. The influence of Ryukyu subduction on magma genesis in the Northern Taiwan Volcanic Zone and Middle Okinawa Trough-Evidence from boron isotopes. Lithos 2016, 260, 242-252. [CrossRef]

50. Shinjo, R.; Chung, S.L.; Kato, Y.; Kimura, M. Geochemical and Sr-Nd isotopic characteristics of volcanic rocks from the Okinawa Trough and Ryukyu Arc: Implications for the evolution of a young, intracontinental back arc basin. J. Geophys Res. Solid Earth 1999, 104, 10591-10608. [CrossRef]

51. Chang-Hwa, C.; Typhoon, L.; Yuch-Ning, S.; Cheng-Hong, C.; Wen-Yu, H. Magmatism at the onset of back-arc basin spreading in the Okinawa Trough. J. Volcanol. Geotherm. Res. 1995, 69, 313-322. [CrossRef]

52. Zengqian, H.; Zaw, K.; Yanhe, L.; Qiling, Z.; Zhigang, Z.; Urabe, T. Contribution of magmatic fluid to the active hydrothermal system in the JADE Field, Okinawa trough: Evidence from fluid inclusions, oxygen and helium isotopes. Int. Geol. Rev. 2010, 47, 420-437. [CrossRef]

53. Zeng, Z.; Yu, S.; Wang, X.; Fu, Y.; Yin, X.; Zhang, G.; Wang, X.; Chen, S. Geochemical and isotopic characteristics of volcanic rocks from the northern East China Sea shelf margin and the Okinawa Trough. Acta Oceanol. Sin. 2010, 29, 48-61. [CrossRef]

54. Lee, C.S.; Shor, G.G.; Bibee, L.D.; Lu, R.S.; Hilde, T.W.C. Okinawa Trough: Origin of a back-arc basin. Mar. Geol. 1980, 35, $219-241$. [CrossRef]

55. Seno, T.; Maruyama, S. Paleogeographic reconstruction and origin of the Philippine Sea. Tectonophysics 1984, 102, 53-84. [CrossRef]

56. Seno, T.; Stein, S.; Gripp, A.E. A model for the motion of the Philippine Sea Plate consistent with NUVEL-1 and geological data. J. Geophys. Res. Solid Earth 1993, 98, 17941-17948. [CrossRef]

57. Hoang, N.; Uto, K. Upper mantle isotopic components beneath the Ryukyu arc system: Evidence for 'back-arc' entrapment of Pacific MORB mantle. Earth Planet. Sci. Lett. 2006, 249, 229-240. [CrossRef]

58. Ishizuka, H.; Kawanobe, Y.; Sakai, H. Petrology and geochemistry of volcanic rocks dredged from the Okinawa Trough, an active back-arc basin. Geochem. J. 1990, 24, 75-92. [CrossRef]

59. Han, B.; Zhang, X.H.; Pei, J.X.; Zhang, W.G. Characteristics of crust-mantle in the East China Sea and adjacent regions. Prog. Geophys. 2007, 22, 376-382.

60. Iwasaki, T.; Hirata, N.; Kanazawa, T.; Melles, J.; Suyehiro, K.; Urabe, T.; Möller, L.; Makris, J.; Shimamura, H. Crustal and upper mantle structure in the Ryukyu Island Arc deduced from deep seismic sounding. Geophys. J. Int. 1990, 102, 631-651. [CrossRef] 
61. Klingelhoefer, F.; Lee, C.S.; Lin, J.Y.; Sibuet, J.C. Structure of the southernmost Okinawa Trough from reflection and wide-angle seismic data. Tectonophys 2009, 466, 281-288. [CrossRef]

62. Liu, B.; Li, S.Z.; Suo, Y.H.; Li, G.X.; Dai, L.M.; Somerville, I.D.; Guo, L.L.; Zhao, S.J.; Yu, S. The geological nature and geodynamics of the Okinawa Trough, Western Pacific. Geol. J. 2016, 51, 416-428. [CrossRef]

63. Nakahigashi, K.; Shinohara, M.; Suzuki, S.; Hino, R.; Shiobara, H.; Takenaka, H.; Nishino, M.; Sato, T.; Yoneshima, S.; Kanazawa, T. Seismic structure of the crust and uppermost mantle in the incipient stage of back arc rifting-Northernmost Okinawa Trough. Geophys Res. Lett. 2004, 31, L02614. [CrossRef]

64. Sibuet, J.C.; Hsu, S.K.; Shyu, C.T.; Liu, C.S. Structural and kinematic evolutions of the Okinawa Trough backarc basin. In Backarc Basins: Tectonics and Magmatism; Taylor, B., Ed.; Springer: Boston, MA, USA, 1995; pp. 343-379.

65. Arai, R.; Kodaira, S.; Yuka, K.; Takahashi, T.; Miura, S.; Kaneda, Y. Crustal structure of the southern Okinawa Trough: Symmetrical rifting, submarine volcano, and potential mantle accretion in the continental back-arc basin. J. Geophys Res. Solid Earth 2017, 122, 622-641. [CrossRef]

66. Furukawa, M.; Tokuyama, H.; Abe, S.; Nishizawa, A.; Kinoshita, H. Report on DELP 1988 cruises in the Okinawa Trough: Part 2. seismic reflection studies in the southwestern part of the Okinawa Trough. Bull. Earthq Res. Inst. Univ. Tokyo 1991, 66, 17-36.

67. Letouzey, J.; Kimura, M. Okinawa Trough genesis: Structure and evolution of a backarc basin developed in a continent. Mar. Pet. Geol. 1985, 2, 111-130. [CrossRef]

68. Sibuet, J.C.; Deffontaines, B.; Hsu, S.K.; Thareau, N.; Le Formal, J.P.; Liu, C.S. Okinawa trough backarc basin: Early tectonic and magmatic evolution. J. Geophys Res. Solid Earth 1998, 103, 30245-30267. [CrossRef]

69. Argus, D.F.; Gordon, R.G.; DeMets, C. Geologically current motion of 56 plates relative to the no-net-rotation reference frame. Geochem. Geophys Geosyst 2011, 12, Q11001. [CrossRef]

70. Kubo, A.; Fukuyama, E. Stress field along the Ryukyu Arc and the Okinawa Trough inferred from moment tensors of shallow earthquakes. Earth Planet. Sci. Lett. 2003, 210, 305-316. [CrossRef]

71. Pezzopane, S.K.; Wesnousky, S.G. Large earthquakes and crustal deformation near Taiwan. J. Geophys Res. 1989, 94, 7250-7264. [CrossRef]

72. Li, W.; Yang, Z.; Wang, Y.; Zhang, B. The petrochemical features of the volcanic rocks in the Okinawa Trough and their geological significance. Acta Petrol. Sin. 1997, 13, 538-550.

73. Shinjo, R.; Kato, Y. Geochemical constraints on the origin of bimodal magmatism at the Okinawa Trough, an incipient back-arc basin. Lithos 2000, 54, 117-137. [CrossRef]

74. Li, X.; Zeng, Z.; Chen, S.; Ma, Y.; Yang, H.; Zhang, Y.; Chen, Z. Geochemical and Sr-Nd-Pb isotopic compositions of volcanic rocks from the Iheya Ridge, the middle Okinawa Trough: Implications for petrogenesis and a mantle source. Acta Oceanol Sin. 2018, 37, 73-88. [CrossRef]

75. Chen, Z.; Zeng, Z.; Wang, X.; Zhang, Y.; Yin, X.; Chen, S.; Ma, Y.; Li, X.; Qi, H. Mineral chemistry indicates the petrogenesis of rhyolite from the southwestern Okinawa Trough. J. Ocean. Univ. China 2017, 16, 1097-1108. [CrossRef]

76. Ishikawa, M.; Sato, H.; Furukawa, M.; Kimura, M.; Kato, Y.; Tsugaru, R.; Shimamura, K. Report on DELP 1988 cruises in the Okinawa Trough: Part 6. petrology of volcanic rocks. Bull. Earthq. Res. Inst. Univ. Tokyo 1991, 66, 151-177.

77. Gao, Y.; Casey, J.F. Lithium isotope composition of ultramafic geological reference materials JP-1 and DTS-2. Geostand Geoanal Res. 2012, 36, 75-81. [CrossRef]

78. Rudnick, R.L.; Tomascak, P.B.; Njo, H.B.; Gardner, L.R. Extreme lithium isotopic fractionation during continental weathering revealed in saprolites from South Carolina. Chem. Geol. 2004, 212, 45-57. [CrossRef]

79. Flesch, G.D.; Anderson, A.R.; Svec, H.J. A secondary isotopic standard for ${ }^{6} \mathrm{Li} /{ }^{7} \mathrm{Li}$ determinations. Int. J. Mass Spectrom. Ion. Phys. 1973, 12, 265-272. [CrossRef]

80. Zheng, Y.F.; Wang, Z.R.; Li, S.G.; Zhao, Z.F. Oxygen isotope equilibrium between eclogite minerals and its constraints on mineral Sm-Nd chronometer. Geochim. Cosmochim. Acta 2002, 66, 625-634. [CrossRef]

81. Zheng, Y.F.; Fu, B.; Li, Y.; Xiao, Y.; Li, S. Oxygen and hydrogen isotope geochemistry of ultrahigh-pressure eclogites from the Dabie Mountains and the Sulu terrane. Earth Planet. Sci. Lett. 1998, 155, 113-129. [CrossRef]

82. Gong, B.; Zheng, Y.F.; Chen, R.X. TC/EA-MS online determination of hydrogen isotope composition and water concentration in eclogitic garnet. Phys. Chem. Min. 2007, 34, 687-698. [CrossRef]

83. An, Y.; Wu, F.; Xiang, Y.; Nan, X.; Yu, X.; Yang, J.; Yu, H.; Xie, L.; Huang, F. High-precision Mg isotope analyses of low-Mg rocks by MC-ICP-MS. Chem. Geol. 2014, 390, 9-21. [CrossRef]

84. Putirka, K.; Condit, C.D. Cross section of a magma conduit system at the margin of the Colorado Plateau. Geology 2003, 31, 701-704. [CrossRef]

85. Putirka, K.D. Thermometers and barometers for volcanic systems. Rev. Mineral. Geochem. 2008, 69, 61-120. [CrossRef]

86. Irvine, T.N.; Baragar, W.R.A. A guide to the chemical classification of the common volcanic rocks. Can. J. Earth Sci. 1971, 8 , 523-548. [CrossRef]

87. Le Maitre, R.W. A classification of Igneous Rocks and Glossary of Terms: Recommendations of the International Union of Geological Sci.ences Subcommission on the Systematics of Igneous Rocks; Blackwell: Oxford, UK, 1989.

88. Roberts, M.P.; Clemens, J.D. Origin of high-potassium, talc-alkaline, I-type granitoids. Geology 1993, 21, 825-828. [CrossRef]

89. Hu, Y.; Niu, Y.; Li, J.; Ye, L.; Kong, J.; Chen, S.; Zhang, Y.; Zhang, G. Petrogenesis and tectonic significance of the late Triassic mafic dikes and felsic volcanic rocks in the East Kunlun Orogenic Belt, Northern Tibet Plateau. Lithos 2016, 245, 205-222. [CrossRef] 
90. Sun, S.S.; McDonough, W.F. Chemical and isotopic systematics of oceanic basalts: Implications for mantle composition and processes. Geol. Soc. Lond. Spec. Publ. 1989, 42, 313-345. [CrossRef]

91. Elliott, T.; Thomas, A.; Jeffcoate, A.; Niu, Y. Lithium isotope evidence for subduction-enriched mantle in the source of mid-oceanridge basalts. Nature 2006, 443, 565-568. [CrossRef]

92. Nishio, Y.; Nakai, S.i.; Ishii, T.; Sano, Y. Isotope systematics of Li, Sr, Nd, and volatiles in Indian Ocean MORBs of the Rodrigues Triple Junction: Constraints on the origin of the DUPAL anomaly. Geochim. Cosmochim. Acta 2007, 71, 745-759. [CrossRef]

93. Tomascak, P.B.; Langmuir, C.H.; le Roux, P.J.; Shirey, S.B. Lithium isotopes in global mid-ocean ridge basalts. Geochim. Cosmochim. Acta 2008, 72, 1626-1637. [CrossRef]

94. Brant, C.; Coogan, L.A.; Gillis, K.M.; Seyfried, W.E.; Pester, N.J.; Spence, J. Lithium and Li-isotopes in young altered upper oceanic crust from the East Pacific Rise. Geochim. Cosmochim. Acta 2012, 96, 272-293. [CrossRef]

95. James, R.H.; Rudnicki, M.D.; Palmer, M.R. The alkali element and boron geochemistry of the Escanaba Trough sediment-hosted hydrothermal system. Earth Planet. Sci. Lett. 1999, 171, 157-169. [CrossRef]

96. Leeman, W.P.; Tonarini, S.; Chan, L.H.; Borg, L.E. Boron and lithium isotopic variations in a hot subduction zone-the southern Washington Cascades. Chem. Geol. 2004, 212, 101-124. [CrossRef]

97. Zhang, L.; Chan, L.H.; Gieskes, J.M. Lithium isotope geochemistry of pore waters from ocean drilling program Sites 918 and 919 Irminger Basin. Geochim. Cosmochim. Acta 1998, 62, 2437-2450. [CrossRef]

98. Teng, F.Z.; McDonough, W.F.; Rudnick, R.L.; Dalpé, C.; Tomascak, P.B.; Chappell, B.W.; Gao, S. Lithium isotopic composition and concentration of the upper continental crust. Geochim. Cosmochim. Acta 2004, 68, 4167-4178. [CrossRef]

99. Cooper, K.M.; Eiler, J.M.; Sims, K.W.W.; Langmuir, C.H. Distribution of recycled crust within the upper mantle: Insights from the oxygen isotope composition of MORB from the Australian-Antarctic Discordance. Geochem. Geophys. Geosyst. 2009, 10, Q12004. [CrossRef]

100. Eiler, J.M.; Schiano, P.; Kitchen, N.; Stolper, E.M. Oxygen-isotope evidence for recycled crust in the sources of mid-ocean-ridge basalts. Nature 2000, 403, 530-534. [CrossRef]

101. Ito, E.; White, W.M.; Göpel, C. The O, Sr, Nd and Pb isotope geochemistry of MORB. Chem. Geol. 1987, 62, 157-176. [CrossRef]

102. Gregory, R.T.; Taylor, H.P. An oxygen isotope profile in a section of Cretaceous oceanic crust, Samail Ophiolite, Oman: Evidence for $\delta 180$ buffering of the oceans by deep $(>5 \mathrm{~km})$ seawater-hydrothermal circulation at mid-ocean ridges. J. Geophys Res. Solid Earth 1981, 86, 2737-2755. [CrossRef]

103. Staudigel, H.; Davies, G.R.; Hart, S.R.; Marchant, K.M.; Smith, B.M. Large scale isotopic Sr, Nd and O isotopic anatomy of altered oceanic crust: DSDP/ODP sites417/418. Earth Planet. Sci. Lett. 1995, 130, 169-185. [CrossRef]

104. Alt, J.; Shanksiii, W. Stable isotope compositions of serpentinite seamounts in the Mariana forearc: Serpentinization processes, fluid sources and sulfur metasomatism. Earth Planet. Sci. Lett. 2006, 242, 272-285. [CrossRef]

105. Simon, L.; Lécuyer, C. Continental recycling: The oxygen isotope point of view. Geochem. Geophys Geosyst. 2005, 6, Q08004. [CrossRef]

106. Bourdon, B.; Tipper, E.T.; Fitoussi, C.; Stracke, A. Chondritic Mg isotope composition of the Earth. Geochim. Cosmochim. Acta 2010, 74, 5069-5083. [CrossRef]

107. Teng, F.Z.; Li, W.Y.; Ke, S.; Marty, B.; Dauphas, N.; Huang, S.; Wu, F.Y.; Pourmand, A. Magnesium isotopic composition of the Earth and chondrites. Geochim. Cosmochim. Acta 2010, 74, 4150-4166. [CrossRef]

108. Teng, F.Z.; Hu, Y.; Chauvel, C. Magnesium isotope geochemistry in arc volcanism. Proc. Natl. Acad. Sci. USA 2016, 113, 7082-7087. [CrossRef]

109. Li, W.Y.; Teng, F.Z.; Ke, S.; Rudnick, R.L.; Gao, S.; Wu, F.Y.; Chappell, B.W. Heterogeneous magnesium isotopic composition of the upper continental crust. Geochim. Cosmochim. Acta 2010, 74, 6867-6884. [CrossRef]

110. Eiler, J.M. Oxygen isotope variations of basaltic lavas and upper mantle rocks. Rev. Miner. Geochem. 2001, 43, 319-364. [CrossRef]

111. Mattey, D.; Lowry, D.; Macpherson, C. Oxygen isotope composition of mantle peridotite. Earth Planet. Sci. Lett. 1994, 128, 231-241. [CrossRef]

112. Beattie, P. Olivine-melt and orthopyroxene-melt equilibria. Contrib. Miner. Pet. 1993, 115, 103-111. [CrossRef]

113. Davis, B.T.C.; Boyd, F.R. The join Mg2Si2O6-CaMgSi2O6at 30 kilobars pressure and its application to pyroxenes from kimberlites. J. Geophys Res. 1966, 71, 3567-3576. [CrossRef]

114. Rudnick, R.L.; Gao, S. Composition of the continental crust. In Treatise on Geochemistry; Holland, H.D., Turekian, K.K., Eds.; Elsevier: Amsterdam, The Netherlands, 2003; Volume 3, pp. 1-64.

115. Park, S.H.; Lee, S.M.; Kamenov, G.D.; Kwon, S.T.; Lee, K.Y. Tracing the origin of subduction components beneath the South East rift in the Manus Basin, Papua New Guinea. Chem. Geol. 2010, 269, 339-349. [CrossRef]

116. Hong, L.B.; Zhang, Y.H.; Qian, S.P.; Liu, J.Q.; Ren, Z.Y.; Xu, Y.G. Constraints from melt inclusions and their host olivines on the petrogenesis of Oligocene-Early Miocene Xindian basalts, Chifeng area, North China Craton. Contrib. Miner. Pet. 2013, 165, 305-326. [CrossRef]

117. Sun, H.; Xiao, Y.; Gao, Y.; Lai, J.; Hou, Z.; Wang, Y. Fluid and melt inclusions in the Mesozoic Fangcheng basalt from North China Craton: Implications for magma evolution and fluid/melt-peridotite reaction. Contrib. Miner. Pet. 2013, 165, 885-901. [CrossRef]

118. Zhang, Y.; Zeng, Z.; Li, X.; Yin, X.; Wang, X.; Chen, S.; Li, S. High-potassium volcanic rocks from the Okinawa Trough: Implications for a cryptic potassium-rich and DUPAL-like source. Geol. J. 2018, 53, 1755-1766. [CrossRef] 
119. Prægel, N.O.; Holm, P.M. Lithospheric contributions to high-MgO basanites from the Cumbre Vieja Volcano, La Palma, Canary Islands and evidence for temporal variation in plume influence. J. Volcanol. Geotherm. Res. 2006, 149, 213-239. [CrossRef]

120. Zhang, H.F.; Sun, M. Geochemistry of Mesozoic basalts and mafic dikes, southeastern North China Craton, and tectonic implications. Int. Geol. Rev. 2002, 44, 370-382. [CrossRef]

121. Zhang, J.J.; Zheng, Y.F.; Zhao, Z.F. Geochemical evidence for interaction between oceanic crust and lithospheric mantle in the origin of Cenozoic continental basalts in east-central China. Lithos 2009, 110, 305-326. [CrossRef]

122. Liu, Y.; Gao, S.; Gao, C.; Zong, K.; Hu, Z.; Ling, W. Garnet-rich granulite xenoliths from the Hannuoba basalts, North China: Petrogenesis and implications for the Mesozoic crust-mantle interaction. J. Earth Sci. 2010, 21, 669-691. [CrossRef]

123. Moriguti, T.; Shibata, T.; Nakamura, E. Lithium, boron and lead isotope and trace element systematics of Quaternary basaltic volcanic rocks in northeastern Japan: Mineralogical controls on slab-derived fluid composition. Chem. Geol. 2004, 212, 81-100. [CrossRef]

124. Tomascak, P.B.; Widom, E.; Benton, L.D.; Goldstein, S.L.; Ryan, J.G. The control of lithium budgets in island arcs. Earth Planet. Sci. Lett. 2002, 196, 227-238. [CrossRef]

125. Grove, T.; Parman, S.; Bowring, S.; Price, R.; Baker, M. The role of an $\mathrm{H}_{2} \mathrm{O}$-rich fluid component in the generation of primitive basaltic andesites and andesites from the Mt. Shasta region, N California. Contrib. Mineral. Petrol. 2002, 142, 375-396. [CrossRef]

126. Handley, H.K.; Macpherson, C.G.; Davidson, J.P.; Berlo, K.; Lowry, D. Constraining fluid and sediment contributions to subduction-related magmatism in Indonesia: Ijen volcanic complex. J. Pet. 2007, 48, 1155-1183. [CrossRef]

127. Magna, T.; Wiechert, U.; Grove, T.L.; Halliday, A.N. Lithium isotope fractionation in the southern Cascadia subduction zone. Earth Planet. Sci. Lett. 2006, 250, 428-443. [CrossRef]

128. Decitre, S.; Deloule, E.; Reisberg, L.; James, R.; Agrinier, P.; Mével, C. Behavior of Li and its isotopes during serpentinization of oceanic peridotites. Geochem. Geophys Geosyst 2002, 3, 1-20. [CrossRef]

129. Lui-Heung, C.; Gieskes, J.M.; Chen-Feng, Y.; Edmond, J.M. Lithium isotope geochemistry of sediments and hydrothermal fluids of the Guaymas Basin, Gulf of California. Geochim. Cosmochim. Acta 1994, 58, 4443-4454. [CrossRef]

130. Tomascak, P.B.; Carlson, R.W.; Shirey, S.B. Accurate and precise determination of Li isotopic compositions by multi-collector sector ICP-MS. Chem. Geol. 1999, 158, 145-154. [CrossRef]

131. Chan, L.H.; Frey, F.A. Lithium isotope geochemistry of the Hawaiian plume: Results from the Hawaii Scientific Drilling Project and Koolau Volcano. Geochem. Geophys. Geosyst. 2003, 4, 8707. [CrossRef]

132. Ryan, J.G.; Langmuir, C.H. The systematics of lithium abundances in young volcanic rocks. Geochim. Cosmochim. Acta 1987, 51, 1727-1741. [CrossRef]

133. Bindeman, I.N.; Ponomareva, V.V.; Bailey, J.C.; Valley, J.W. Volcanic arc of Kamchatka: A province with high- $\delta^{18} \mathrm{O}$ magma sources and large-scale ${ }^{18} \mathrm{O} /{ }^{16} \mathrm{O}$ depletion of the upper crust. Geochim. Cosmochim. Acta 2004, 68, 841-865. [CrossRef]

134. Bindeman, I. Oxygen isotopes in mantle and crustal magmas as revealed by single crystal analysis. Rev. Miner. Geochem. 2008, 69, 445-478. [CrossRef]

135. Auer, S.; Bindeman, I.; Wallace, P.; Ponomareva, V.; Portnyagin, M. The origin of hydrous, high- $\delta^{18} \mathrm{O}$ voluminous volcanism: Diverse oxygen isotope values and high magmatic water contents within the volcanic record of Klyuchevskoy volcano, Kamchatka, Russia. Contrib Miner. Pet. 2009, 157, 209-230. [CrossRef]

136. Dorendorf, F.; Wiechert, U.; Wörner, G. Hydrated sub-arc mantle: A source for the Kluchevskoy volcano, Kamchatka/Russia. Earth Planet. Sci. Lett. 2000, 175, 69-86. [CrossRef]

137. Perkins, G.B.; Sharp, Z.D.; Selverstone, J. Oxygen isotope evidence for subduction and rift-related mantle metasomatism beneath the Colorado Plateau-Rio Grande rift transition. Contrib. Miner. Pet. 2006, 151, 633-650. [CrossRef]

138. Harmon, R.S.; Hoefs, J. Oxygen isotope heterogeneity of the mantle deduced from global $18 \mathrm{O}$ systematics of basalts from different geotectonic settings. Contrib Miner. Pet. 1995, 120, 95-114. [CrossRef]

139. Wang, Z.; Eiler, J. Insights into the origin of low $-\delta^{18} \mathrm{O}$ basaltic magmas in Hawaii revealed from in situ measurements of oxygen isotope compositions of olivines. Earth Planet. Sci. Lett. 2008, 269, 377-387. [CrossRef]

140. Wei, C.S.; Zheng, Y.F.; Zhao, Z.F.; Valley, J.W. Oxygen and neodymium isotope evidence for recycling of juvenile crust in northeast China. Geology 2002, 30, 375-378. [CrossRef]

141. Muehlenbachs, K. Alteration of the oceanic crust and the ${ }^{18} \mathrm{O}$ history of seawater. In Stable Isotopes in High Temperature Geological Processes; Valley, J.W., Taylor, H.P., O’Neil, J.R., Eds.; De Gruyter: Berlin, Germany, 1986; pp. 425-444.

142. Cooper, K.M.; Eiler, J.M.; Asimow, P.D.; Langmuir, C.H. Oxygen isotope evidence for the origin of enriched mantle beneath the mid-Atlantic ridge. Earth Planet. Sci. Lett. 2004, 220, 297-316. [CrossRef]

143. Demény, A.; Vennemann, T.W.; Hegner, E.; Nagy, G.; Milton, J.A.; Embey-Isztin, A.; Homonnay, Z.; Dobosi, G. Trace element and $\mathrm{C}-\mathrm{O}-\mathrm{Sr}-\mathrm{Nd}$ isotope evidence for subduction-related carbonate-silicate melts in mantle xenoliths (Pannonian Basin, Hungary). Lithos 2004, 75, 89-113. [CrossRef]

144. Eiler, J.M.; Farley, K.A.; Valley, J.W.; Hauri, E.; Craig, H.; Hart, S.R.; Stolper, E.M. Oxygen isotope variations in ocean island basalt phenocrysts. Geochim. Cosmochim. Acta 1997, 61, 2281-2293. [CrossRef]

145. Xia, Q.K.; Dallai, L.; Deloule, E. Oxygen and hydrogen isotope heterogeneity of clinopyroxene megacrysts from Nushan Volcano, SE China. Chem. Geol. 2004, 209, 137-151. [CrossRef]

146. Liu, P.P.; Teng, F.Z.; Dick, H.J.B.; Zhou, M.F.; Chung, S.L. Magnesium isotopic composition of the oceanic mantle and oceanic Mg cycling. Geochim. Cosmochim. Acta 2017, 206, 151-165. [CrossRef] 
147. Handler, M.R.; Baker, J.A.; Schiller, M.; Bennett, V.C.; Yaxley, G.M. Magnesium stable isotope composition of Earth's upper mantle. Earth Planet. Sci. Lett. 2009, 282, 306-313. [CrossRef]

148. Ionov, D.A. Petrology of mantle wedge lithosphere: New data on supra-subduction zone peridotite xenoliths from the andesitic Avacha volcano, Kamchatka. J. Pet. 2010, 51, 327-361. [CrossRef]

149. Teng, F.Z.; Wadhwa, M.; Helz, R.T. Investigation of magnesium isotope fractionation during basalt differentiation: Implications for a chondritic composition of the terrestrial mantle. Earth Planet. Sci. Lett. 2007, 261, 84-92. [CrossRef]

150. Yang, W.; Teng, F.Z.; Zhang, H.F. Chondritic magnesium isotopic composition of the terrestrial mantle: A case study of peridotite xenoliths from the North China craton. Earth Planet. Sci. Lett. 2009, 288, 475-482. [CrossRef]

151. Wimpenny, J.; Yin, Q.Z.; Tollstrup, D.; Xie, L.W.; Sun, J. Using Mg isotope ratios to trace Cenozoic weathering changes: A case study from the Chinese Loess Plateau. Chem. Geol. 2014, 376, 31-43. [CrossRef]

152. Li, W.Y.; Teng, F.Z.; Xiao, Y.; Huang, J. High-temperature inter-mineral magnesium isotope fractionation in eclogite from the Dabie orogen, China. Earth Planet. Sci. Lett. 2011, 304, 224-230. [CrossRef]

153. Von Strandmann, P.A.E.P.; Elliott, T.; Marschall, H.R.; Coath, C.; Lai, Y.J.; Jeffcoate, A.B.; Ionov, D.A. Variations of Li and Mg isotope ratios in bulk chondrites and mantle xenoliths. Geochim. Cosmochim. Acta 2011, 75, 5247-5268. [CrossRef]

154. Hacker, B.R. $\mathrm{H}_{2} \mathrm{O}$ subduction beyond arcs. Geochem. Geophys. Geosyst. 2008, 9, Q03001. [CrossRef]

155. Magni, V.; Faccenna, C.; van Hunen, J.; Funiciello, F. How collision triggers backarc extension: Insight into Mediterranean style of extension from 3-D numerical models. Geology 2014, 42, 511-514. [CrossRef]

156. Peacock, S.M.; Wang, K. Seismic consequences of warm versus cool subduction metamorphism: Examples from southwest and northeast Japan. Science 1999, 286, 937-939. [CrossRef]

157. Van Keken, P.E.; Hacker, B.R.; Syracuse, E.M.; Abers, G.A. Subduction factory: 4. Depth-dependent flux of $\mathrm{H}_{2} \mathrm{O}$ from subducting slabs worldwide. J. Geophys. Res. 2011, 116, B01401. [CrossRef]

158. Zheng, Y.F.; Chen, R.X.; Xu, Z.; Zhang, S.B. The transport of water in subduction zones. Sci. China Earth Sci. 2016, 59, 651-682. [CrossRef]

159. Ko, Y.T.; Kuo, B.Y.; Wang, K.L.; Lin, S.C.; Hung, S.H. The southwestern edge of the Ryukyu subduction zone: A high Q mantle wedge. Earth Planet. Sci. Lett. 2012, 335-336, 145-153. [CrossRef] 